\title{
Impact of storms on residence times and export of coastal waters during a mild autumn/winter period in the Gulf of Lion
}

\author{
Mikolajczak Guillaume 1, ${ }^{*}$, Estournel Claude 1, Ulses Caroline 1, Marsaleix Patrick ${ }^{1}$, Bourrin Francois ${ }^{2}$, \\ Martin Jacobo ${ }^{3}$, Pairaud Ivane ${ }^{4}$, Puig Pere ${ }^{5}$, Leredde Yann ${ }^{6}$, Many Gael ${ }^{7}$, Seyfried Leo ${ }^{7}$, \\ Durrieu De Madron Xavier ${ }^{2}$
}

1 Univ Toulouse, LEGOS, CNES, CNRS,IRD,UPS, Toulouse, France.

2 CNRS, Ctr Rech \& Format Environm Mediterraneens, UMR 5110, 52 Ave Paul Alduy, F-66860

Perpignan, France.

${ }^{3}$ CADIC CONICET, Bernardo Houssay 200, RA-9410 Ushuaia, Argentina.

${ }^{4}$ Ctr Mediterranee, CS20 330, F-83507 La Seyne Sur Mer, France.

5 ICM CSIC, Passeig Maritim Barceloneta 37-49, Barcelona 08003, Spain.

6 Univ Montpellier, Geosci Montpellier, UMR 5243, CNRS, PI E Bataillon, F-34095 Montpellier 5, France.

7 Univ Toulouse, Lab Aerol, UPS, CNRS, Toulouse, France.

* Corresponding author : Guillaume Mikolajzak, email address : guillaume.mikolajczak@aero.obs-mip.fr

\begin{abstract}
:
A coupled ocean-wave model was used to investigate residence times of the water masses on the Gulf of Lion shelf and their export routes during autumn 2010 and winter 2010-2011. Particular attention is paid to the Cap de Creus region and submarine canyon, a key site for the export of water from the Gulf of Lion shelf. First, model results were compared to numerous observations taken during the same period. The timing of strong current pulses on the shelf and at $300 \mathrm{~m}$ depth within the Cap de Creus Canyon, linked to easterly winds during winter, were well reproduced by the model. Lagrangian particle trajectories were used to calculate residence times of water masses on the Gulf of Lion shelf. Those of waters located near the Rhone River ranged from 10 to 40 days for autumn 2010, a period which was dominated by frequent strong winds, to 40-60 days for winter 2010-2011, which has been linked to less frequent strong winds and a slope current flowing farther away from the shelf. In the Cap de Creus region the volumes of water exported were estimated at $747 \mathrm{~km}(3)$ in autumn and $1513 \mathrm{~km}(3)$ in winter. Results show that, in autumn, only $4 \%$ of the water was exported at depths below $200 \mathrm{~m}$ while, in winter, this percentage was $25 \%$ because it was related to coastal dense water cascades. Yet, this export remains low compared to other winters. It is likely that the low heat losses that characterized the second part of the winter were responsible for the shallow export depth through the Cap de Creus Canyon. These conditions favoured an export of water from the Gulf of Lion to the Spanish coastal zone that would represent $70 \%$ of the total exported volume. Interannual variability of the distribution of this export was investigated over the longer period of 2010-2017. Heat losses in February and March appear to be an indicator of dense shelf water cascading, suggesting about 3 or 4 out of 8 winters being affected by deep cascading (reaching $1000 \mathrm{~m}$
\end{abstract}


depth). Understanding the variability of exports of continental inputs to this region is essential to anticipate their potential impacts on ecosystems and human activities in environments as contrasting as the coastal zone and deep canyons.

\section{Highlights}

Residence times of coastal waters in the eastern part of the Gulf of Lion range from 15 to 60 days. Export from the Gulf of Lion along the margin is triggered by easterly winds. 2/3 of the export takes place across the coastal strip off the Cap de Creus, $1 / 3$ through the submarine canyon.

Keywords : Hydrodynamic modelling, Coastal water export, Residence time, Storms, Gulf of lion, Mediterranean 


\section{Introduction} nental fresh water and are a buffering zone between the continent and the open ocean. The residence time of these coastal waters plays an important role in issues related to water quality, contaminant dispersion or nutrient and oxygen availability. This concept of residence time has often been addressed in estuaries (Rasmussen and Josefson, 2002), bays (Liu et al., 2004) or

The Gulf of Lion (GoL) is a microtidal region located in the north-western Mediterranean.

tow tidal amplitudes prevent estuarine circulation in the main Mediterranean river that flows

into the GoL : the Rhône. The currents in the Rhône are fast (between 1.5 and $4 \mathrm{~m} \mathrm{~s}^{-1}$ ) and generally directed downstream. The importance of the Rhône is not limited to its water transport (annual average $1700 \mathrm{~m}^{3} \mathrm{~s}^{-1}$ ), nor to its solid transport $\left(8.4 \mathrm{MT} \mathrm{yr}^{-1}+/-4.5 \mathrm{MT}\right.$ $\mathrm{yr}^{-1}$ Sadaoui et al., 2016), but as its watershed is subject to various anthropogenic pressures, it becomes a vector of pollutants in the marine environment. For example, several nuclear power plants occupy the Rhône Valley. In the event of an accident, the river could transport 
radioelements from the continent to the marine environment. A good estimation of the residence time of river water in the coastal zone and then of the export processes would thus be crucial to understand the dispersion of pollutants and contamination of the marine environment.

The ocean circulation of the GoL is influenced by winds, rivers and the Northern Current (Millot, 1999), which is the northern branch of the cyclonic circulation of the western Mediterranean (schematized in Fig. 1) that occasionally penetrates onto the shelf (Gatti et al., 2006; Barrier et al., 2016) and generally represents a density barrier for the coastal waters. The GoL shelf is known to be influenced by three main wind regimes: two north-westerly/northerly (hereafter "northerly") winds and one south-easterly/easterly (hereafter "easterly") wind. The two cold, dry northerly winds (Mistral and Tramontane blowing respectively over the eastern and western parts of the GoL) play a key role in the circulation of the continental shelf (e.g. Estournel et al., 2003; Leredde et al., 2007; Petrenko et al., 2008) and in the loss of buoyancy of coastal waters, especially in winter (Millot, 1990). A high loss of buoyancy can lead to density driven current which can flow down the continental slope. This phenomenon, known as dense shelf water cascading, is highly dependent on the preconditioning of the water column, evaporation and surface cooling. The easterly winds, associated with moist air and low heat losses, are rare and brief. They do not produce a densification of water masses but lead to an intense cyclonic coastal circulation on the GoL continental shelf (Ulses et al., 2008a). It has been shown that these two processes (densification of shelf waters in winter and intense cyclonic circulation) responsible for major exports from the GoL shelf can be decoupled in time (storms occur mainly from autumn to spring while strong water densification occurs in winter), but they can also combine when an easterly storm follows a period of densification in winter (Ulses et al., 2008a). The export routes associated with these processes are generally different and depend on the buoyancy of the coastal waters.

The canyons located on the western part of the GoL (Cap de Creus, hereafter CCC, and Lacaze-Duthiers) play a predominant role in the export of dense coastal waters by guiding them 
105 variability (high frequency to seasonal and interannual) in the residence times and export routes 
of coastal waters in the GoL.

135 This study considers the period from autumn 2010 to spring 2011, which was characterized by alternating winds without major cooling of the coastal water. We used a numerical model in order to complete the available data sets, examine the export pathways in detail and quantify water transport. A two-way coupled ocean and wave model was set up. After a description of the model and of the observations, the assessment of the simulation is presented below. Then, the residence time of the water masses is evaluated by tracking Lagrangian particles, and the spatio-temporal distribution of shelf water export is calculated. The interannual variability of the export depth and pathways is then addressed over a succession of 8 years using a very simplified approach based solely on winter surface heat losses. Finally, some conclusions are presented. 


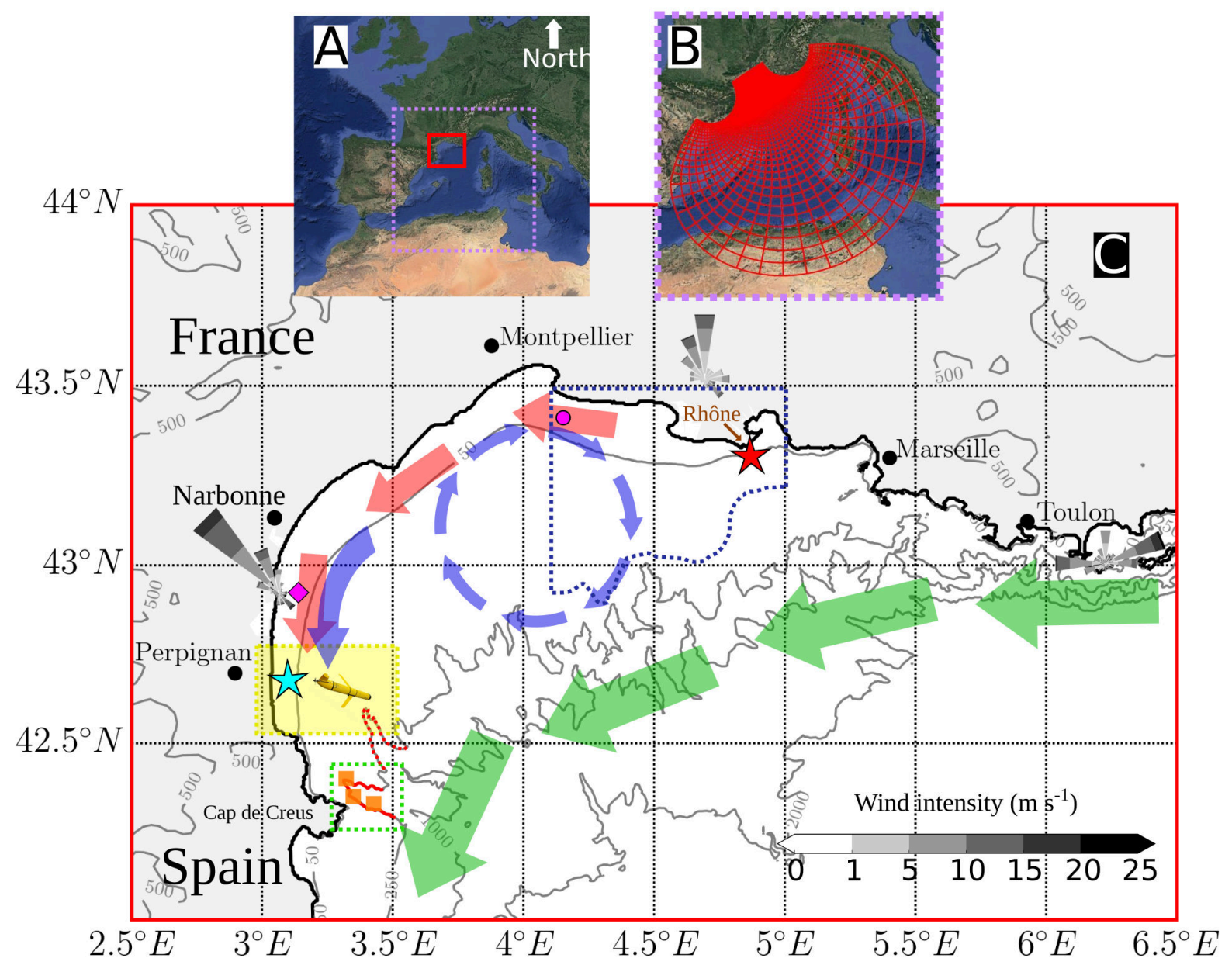

Figure 1: A) Situation of the Gulf of Lion in the western Mediterranean. B) Horizontal grid of the numerical model SYMPHONIE (one point out of 10). C) Position of the instruments on the Gulf of Lion map, wind roses at 3 meteorological stations (from east to west, Leucate, Arles, Porquerolles) over the period studied. Stars indicate the positions of the MesuRho (red) and POEM (blue) coastal stations. Orange squares mark the position of the three moorings in the Cap de Creus canyon, from north to south: Canyon Head (CH) and southern flank (SF1 and SF2). The pink diamond and circle represent the Leucate and Espiguette wave buoy recorder. Yellow box: glider trajectory area. Green box: CTD profile area. Blue dotted box: deployment zone of the Lagrangian particles in the model, between $4.2^{\circ} \mathrm{E}$ and $5^{\circ} \mathrm{E}$, and between the coast and the 100 $\mathrm{m}$ isobath. The green arrows represent the Northern Current. The red and blue arrows represent the current patterns for easterly winds and northerly winds, respectively. The isobaths underlined in red represent the canyons of Lacaze-Duthiers to the north (dotted line) and Cap de Creus to the south (solid line). 


\subsection{Numerical modelling}

\subsubsection{Wave-current coupled ocean model}

a Simulations were performed with the SYMPHONIE ocean circulation model (Marsaleix et al. 2008, 2009, 2012) coupled with the WW3 wave generation and propagation model (Tolman and others, 2009). Several authors (e.g. Uchiyama et al., 2010) have indicated that swell, especially in the surf zone, transfers energy to the current and increases turbulence in the surface layer. For example, Michaud et al. (2012) have shown that using the same coupled model as employed here, but with a $22 \mathrm{~m}$ horizontal grid, gives a better representation of currents during storms. The parameterization of the combined wave-current interaction is described in Ardhuin et al. (2008), and its implementation in the SYMPHONIE ocean circulation model is detailed in Michaud et al. (2012). The wave and ocean circulation models are coupled with a 4-minutes time step using the OASIS3-MCT coupler already implemented in SYMPHONIE for atmospheric coupling (Voldoire et al., 2017; Seyfried et al., 2017). The ocean model provides the water height and surface current to the wave model. The wave model provides the circulation model with significant wave height, breaking wave height, peak wave direction and period, Stokes velocities, surface wave kinetic energy flux, and momentum fluxes from the atmosphere to waves and from waves to the ocean. The variables exchanged are averaged during the coupling time step before being communicated. The numerical grid of the circulation model is a curvilinear bipolar (Bentsen et al., 1999) Arakawa C-grid with 40 generalized sigma levels on the vertical. The bipolar grid allows a horizontal resolution between 300 and $500 \mathrm{~m}$ to be obtained over the entire GoL shelf and gradually lowers the resolution towards the south of the domain (around $7 \mathrm{~km}$ along the Algerian coast, Fig. 1B). This numerical grid makes it possible to move the open boundaries to a significant distance from the GoL while maintaining more than half of the grid points in the area of interest.

According to the results we obtained (not shown here) moving the boundaries apart allows a better representation of the general characteristics of the North Current (position, width, strength). A variation in the residence times of coastal water masses of $8 \%$ maximum was obtained with the results of a sensitivity test where the boundaries are located near the entrance 
of the Gulf of Lion shelf.

175 Regarding bathymetry, coastal measurements carried out with airborne LIDAR (http://www.occitanie.developpement-durable.gouv.fr/le-suivi-du-littoral-par-laser-aeroporte-lidarr1893.html) were associated with the lower resolution EMODnet bathymetry (www.emodnetbathymetry.eu). The wave model uses the grid of the circulation model but with a spatial resolution degraded by a factor of two in each direction because this model uses significantly more computer resources than the circulation one. The interpolation of the wave model fields on the grid of the circulation model and the interpolation of the circulation model fields on the wave model grid are bilinear. The period simulated with the coupled current/wave system ran from 15 August 2010 to 1 May 2011.

\subsubsection{Forcing}

\subsubsection{Initial conditions and open boundary conditions}

The initial state and the open boundary conditions of the ocean model were given by a SYMPHONIE "parent" simulation encompassing the western Mediterranean that began two months earlier than our simulation and whose initial state, together with the boundary conditions, were provided by the NEMO model of the MERCATOR-OCEAN operational centre (Lellouche et al., 2013). As explained in Estournel et al. (2016), the NEMO temperature and salinity forcing fields were first corrected to restore a consistent stratification index. As far as the wave model was concerned, it was assumed that the "child" numerical domain was large enough for open boundary conditions to have little influence on the continental shelf of the GoL. The wave field was thus assumed to be in equilibrium with the wind at the open boundaries.

\subsubsection{Tides}

Tidal forcing was considered in the ocean circulation model as described by Pairaud et al. (2008). Velocities and sea surface heights of 9 harmonic components (M2,N2,S2,K2,K1,O1,P1,Q1,M4) were provided by FES2012 products from the FES (Finite Element Solution) global tide model (Carrere et al., 2013). 


\subsubsection{Analysis of the model results}

\subsubsection{Computation of the fate of coastal waters during wind events using Lagrangian particles}

Lagrangian particle tracking was used to monitor the trajectory of the coastal water masses 215

Hydrological forcing was set at the grid points corresponding to the river mouths by using the daily flows provided by the HYDRO database (www.hydro.eaufrance.fr). A seasonal climatology gave the freshwater temperature. The implementation of rivers in the model is described in Estournel et al. (2009).

\subsubsection{Atmospheric conditions}

Atmospheric forcing was provided by the three-hourly forecasts calculated by the European Centre for Medium-Range Weather Forecasts (ECMWF, https://www.ecmwf.int/en/forecasts/accessingforecasts) on a $1 / 8^{\circ}$ resolution, regular grid. The surface turbulent fluxes were calculated using the bulk formulas of Large and Yeager (2004), taking the wind, air temperature, humidity and pressure, and sea surface temperature from the oceanic model.

during northerly and easterly wind events. We used this functionality of the SYMPHONIE model in offline mode to focus on the water masses most likely to be influenced by the Rhône River (Section 4.1). Lagrangian particles were distributed every $0.01^{\circ}$ horizontally and every meter vertically on the shelf near the Rhône, mainly to the west of the Rhône, (between 4.2 and $5^{\circ} \mathrm{E}$, and delimited by the coastline and the $100 \mathrm{~m}$ isobath, blue dotted box in Fig. 1), which is the area known to be influenced by dissolved and particulate inputs from the river (Estournel et al., 1997; Gangloff et al., 2017). They were distributed throughout the water column to take account of both fresh water masses and water masses containing the surface and bottom nepheloid layers that are found in this area (Many et al., 2016).

Particles were released at the start of the main northerly and easterly wind events identified in the time series (see Figures 2 and 3 ). The numerical domain was divided into $10 \mathrm{~km}$ boxes 
in which the numbers of particles present at the end of each event were counted. Then, for each of the two wind regimes (northerly and easterly), the sum of particles was accumulated over the 3 events and then expressed as a percentage of the total number of particles injected into the domain.

\subsubsection{Computation of residence time using Lagrangian particles}

Lagrangian particles were also used to estimate residence times. The residence time is defined here as the time required for $50 \%$ of the particles near the Rhône river mouth to leave the GoL shelf, which is limited here to the $100 \mathrm{~m}$ isobath offshore, $42.26^{\circ} \mathrm{N}$ to the south-west and $5.37^{\circ} \mathrm{E}$ to the east (Fig. 1). The value of the $50 \%$ threshold was chosen to allow the residence time to be calculated over the whole period (for example, a value of $90 \%$ would have limited the calculation to the period October-December 2010). This definition was preferred to the classical e-folding time (Monsen et al., 2002) because the temporal variation of the number of particles present in the domain generally deviates from an exponential curve due to the strong variability of the currents linked to the wind variability. Particles were injected every day (at midnight) from 1 September 2010 to 30 March 2011.

\subsubsection{Winter atmospheric indicators}

ECMWF atmospheric forcing was also used to characterize wind and heat flux conditions for the winters from 2010 to 2017 (Section 5.3). Daily means of wind intensities and directions in the GoL $\left(43.125^{\circ} \mathrm{N} ; 3.875^{\circ} \mathrm{E}\right)$ were used to obtain the number of days with northerly or

easterly wind stronger than $8 \mathrm{~m} \mathrm{~s}^{-1}$. At the same time, the 3-hr surface heat fluxes (produced by ECMWF and no longer computed by our model) averaged over the GoL shelf and over the winter period, were used as a proxy to compare the different years in terms of maximum density achieved during the winter. 


\subsection{Observations used for model validation}

The coastal stations POEM (Bourrin et al., 2015, blue star of Fig. 1) and MesuRho (Pairaud et al., 2016, red star of Fig. 1) are autonomous instrumented surface buoys and benthic platforms that perform high-frequency measurements throughout the water column. The stations belong to the COAST-HF observation network under the ILICO research infrastructure (https://www.ir-ilico.fr/en/The-research-infrastructure/Presentation-and-objectives). The buoys are positioned at depths of $28 \mathrm{~m}$ (POEM) and $20 \mathrm{~m}$ (MesuRho). The benthic platforms are equipped with an upward-looking bottom ADCP (Acoustic Doppler Current Profiler), which measures the current with a vertical resolution of 1 (POEM) or $0.5 \mathrm{~m}$ (MesuRho) from 2 mab (meters above bottom) to the surface, at 5- (POEM) or 15-minute (MesuRho) sampling intervals. In addition, the POEM buoy is equipped with a YSI 6600-EDS CTD probe, set up $1 \mathrm{~m}$ below the surface, which measures the temperature and salinity every 15 minutes. At the MesuRho buoy, temperature and salinity were measured first by an STPS NKE probe at a depth of $2.5 \mathrm{~m}$ during autumn 2010 and second by a SMATCH probe at $2.75 \mathrm{~m}$ from March to April 2011. These data are available from the Coriolis platform (www.coriolis-cotier.org). Finally, wind direction and intensity were also measured at POEM and MesuRho. The sea state parameters are provided at two points, Espiguette on the northern coast (Fig. 1), and a point close to POEM (Leucate, Fig. 1). These fields (significant wave height, period and direction among others) were measured by houlographs of CANDHIS (the French National In-Situ Swell Data Archiving Centre, http://candhis.cetmef.developpement-durable.gouv.fr/).

\subsubsection{Glider data}

One of the particularities of the CASCADE experiment carried out in winter/spring 2011 is the deployment of a SLOCUM glider (Davis et al., 2003) over the GoL continental shelf from 3 March to 28 April 2011. Water temperature and salinity were continuously measured by a pumped SBE 41-CP CTD installed in the glider. Depth-averaged currents were also estimated using the difference between the estimated position of the next waypoint by dead reckoning and the actual position provided by GPS. Several high-resolution transects were made between the 
Lacaze-Duthiers Canyon and POEM site (Fig. 11). A complete description of the instrument and its use is given in Bourrin et al. (2015).

\subsubsection{Mooring sites in the Cap de Creus Canyon}

head over a bottom depth of $300 \mathrm{~m}$, as part of the HYDROCHANGES network (Schroeder et al. 2013). The bottom current and water temperature at 5 mab was recorded every 30 minutes by an Aanderaa RCM9 current meter. During the CASCADE experiment, two temporary moorings (SF1 and SF2, Fig. 1) were deployed from 3 to 21 March 2011 on the southern flank equipped with a downward-looking ADCP (TRDI WHS Sentinel $300 \mathrm{kHz}$ ), positioned at 160 mab, which measured current velocities down to 40 mab with a sampling interval of 15 minutes and a vertical resolution of $2 \mathrm{~m}$. Water temperature was also measured every 3 min at 10, 75 and 115 mab by means of three AQUAlogger (Aquatec Group Ltd) sensors attached to the

\subsubsection{CTD profiles}

During the CASCADE experiment, several CTD profiles (Seabird 911 Plus) were recorded from the R/V L'Atalante Martín et al. (2013). Here, we use a section of temperature and salinity through the canyon measured on 14 March during a strong easterly storm. 


\section{Evaluation of model outputs}

The model outputs were compared with in situ observations performed on the shelf and in the CCC over the study period (section 2.2) to assess the reliability of the model simulations of the hydrology over the shelf, the intensification of currents during storm events and the characteristics of water transport in the canyon.

\subsection{Gulf of Lion continental shelf}

\subsubsection{Time series from moorings}
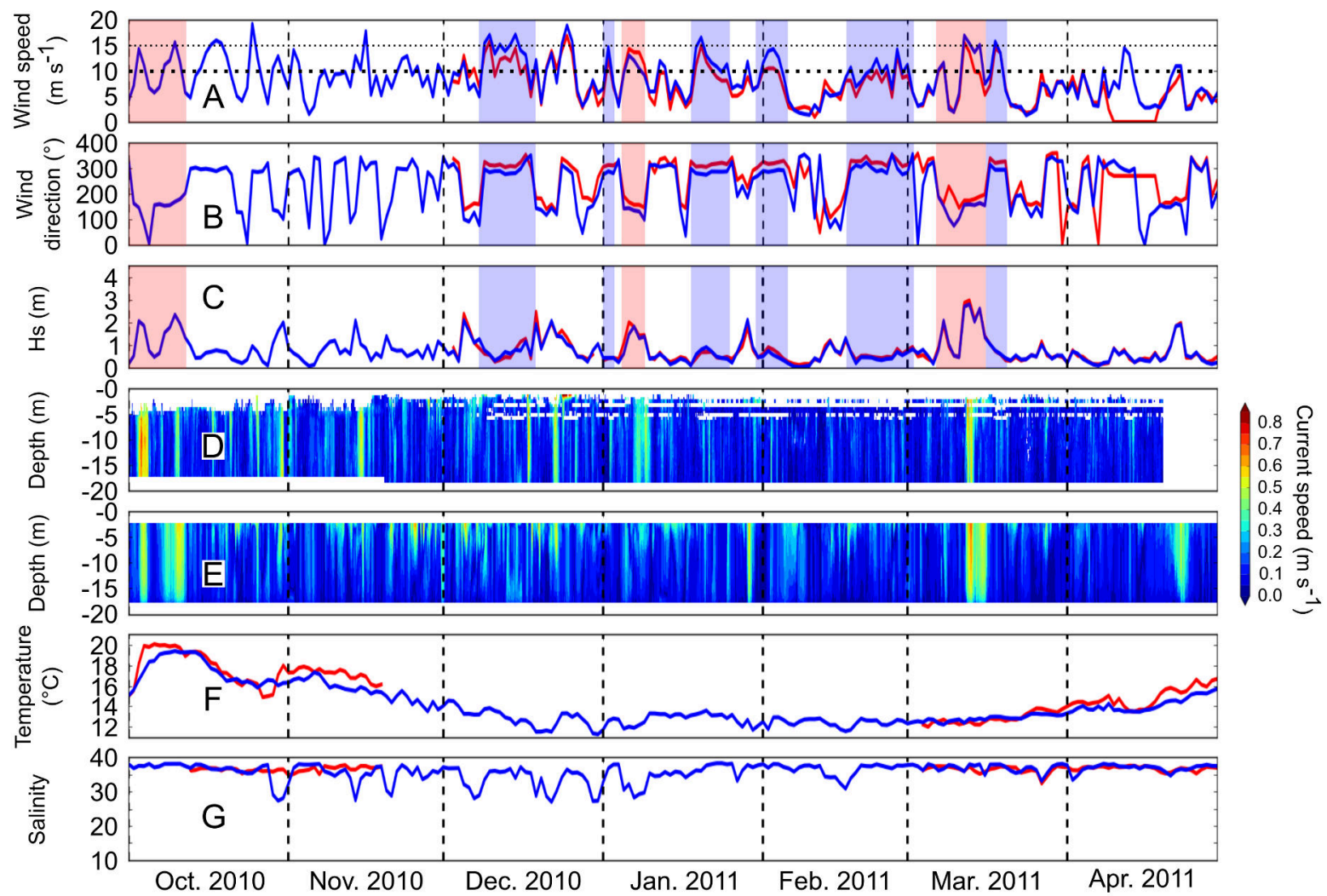

Figure 2: Time evolution of observed and modelled parameters at the MesuRho station (near the Rhône). Wind intensity (A), and direction (B), significant wave height (C). Hovmöller diagram of the observed (D) and simulated (E) current. Daily mean temperature (F) and salinity (G) at $2 \mathrm{~m}$ below the surface. Red line: observation, blue line: model outputs (ECMWF forecasts for wind). Red and blue shaded periods highlight the main easterly and northerly wind events, respectively.

Figures 2 and 3 compare the time evolution of parameters measured and modelled at the MesuRho and POEM coastal stations (Fig. 1). The observed wind intensity throughout the 


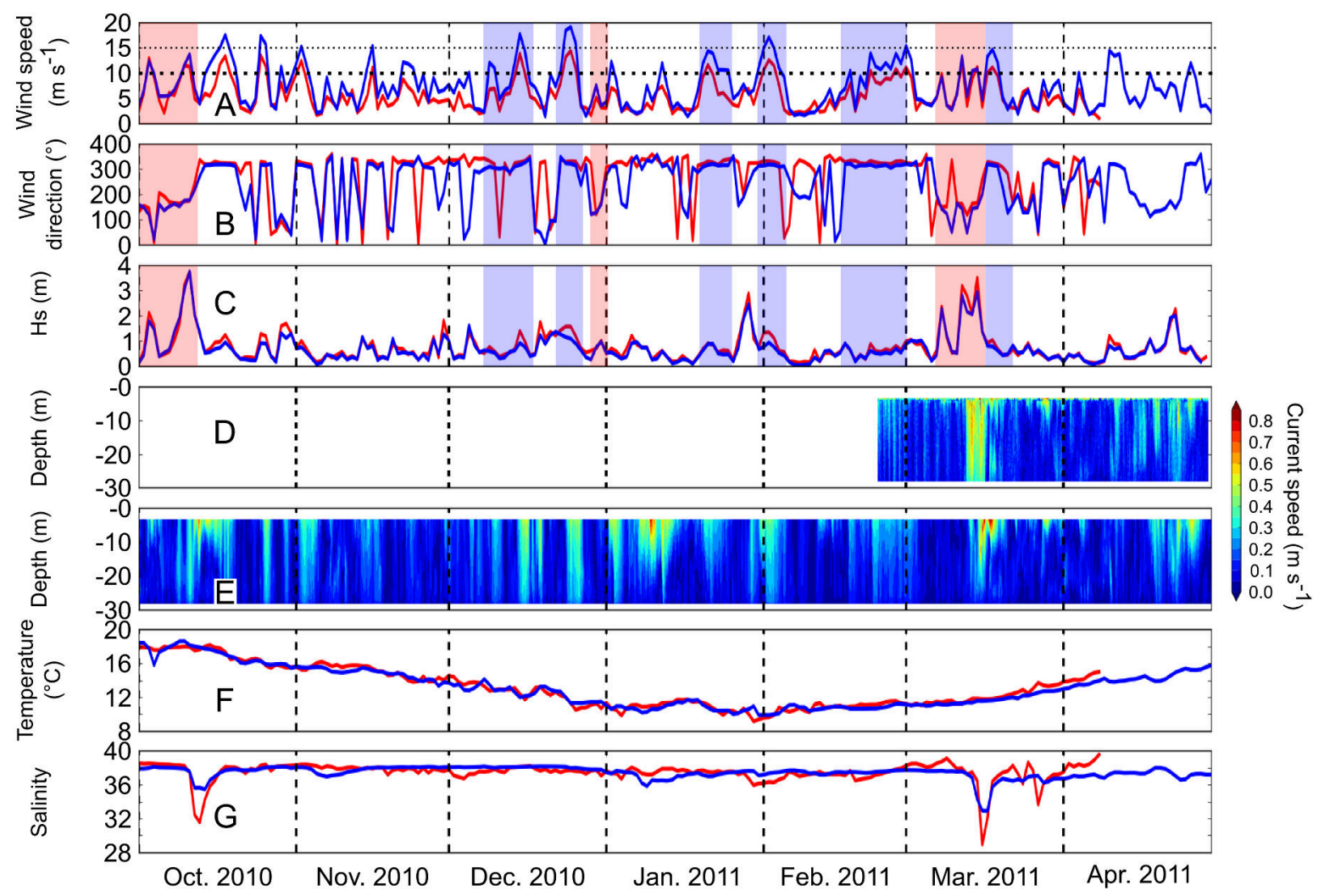

Figure 3: Time evolution of observed and modelled parameters at the POEM station (south-west of the GoL). Wind intensity (A) and direction (B), significant wave height (C). Hovmöller diagram of the observed (D) and simulated (E) current. Daily mean temperature (F) and salinity $(\mathrm{G})$ at $2 \mathrm{~m}$ below the surface. Red line: observation, blue line: model outputs (ECMWF forecasts for wind). Red and blue shaded periods highlight the main easterly and northerly wind events, respectively.

entire period studied was less than $20 \mathrm{~m} \mathrm{~s}^{-1}$ but exceeded $15 \mathrm{~m} \mathrm{~s}^{-1}$ several times (Fig. 2A and 305 3A). Most of these intense winds blew from the north. Easterly winds were also frequent. Their intensities were higher than $10 \mathrm{~m} \mathrm{~s}^{-1}$ at the beginning of October 2010 and during March 2011. Comparisons between the observed wind velocity and direction and the ECMWF forecasts, used to force the ocean model, show excellent correlation at both stations (above $0.90(\mathrm{p}<0.01)$ for velocities). The significant wave height observed at Espiguette buoy to the north (Figs. 2C) was $0.75 \mathrm{~m}$ on average over the whole period and did not exceed $3 \mathrm{~m}$. At Leucate buoy, to the south-west (Fig. 3C), maximum values reached $4 \mathrm{~m}$ under easterly winds. The statistics calculated for the WW3 model show a bias of less than $-0.08 \mathrm{~m}$ and a correlation of 0.97 ( $\mathrm{p}<$ 0.01). The observed current velocity at MesuRho and POEM stations (Figs. 2D and 2E; Figs. 
3D and $3 \mathrm{E}$ ) was generally weak over the water column, with mean values of less than $0.2 \mathrm{~m} \mathrm{~s}^{-1}$. stations) for which the depth-averaged current velocity increased, sometimes exceeding $0.4 \mathrm{~m}$ $\mathrm{s}^{-1}$. The succession of calm and more intense episodes in the model was similar to observations, even though the model underestimated the deep current at the POEM station. Statistics at 10 $\mathrm{m}$ depth at MesuRho and $15 \mathrm{~m}$ depth at POEM (not shown) showed correlations of 0.42 and 0.64 , respectively, with observations and biases of $0.002 \mathrm{~m} \mathrm{~s}^{-1}$ and $0.03 \mathrm{~m} \mathrm{~s}^{-1}$ respectively. The time evolution of temperature simulated and observed at $2 \mathrm{~m}$ below the surface at MesuRho (Figs. 2F and $2 \mathrm{G}$ ) shows that the model reproduced the evolution of the observed temperature correctly (correlation: 0.83 , bias: $0.62{ }^{\circ} \mathrm{C}$ ) between October and November 2010. During the period March-April 2011, the model was even more accurate (correlation: 0.96 , bias $0.34^{\circ} \mathrm{C}$ ). Regarding the time evolution of salinity, two different situations were noticed. During the first period, the high bias (-1.57) and the low correlation (0.01) show the difficulty for the model to reproduce the waters close to the Rhône River. It is likely that the location of the mooring very close to the Rhône mouth, an area characterized by large salinity gradients at kilometric scale across river plumes, made it very difficult to perform such a comparison. On the other hand, the second period was very well represented by the model (correlation: 0.63 , bias: 0.24 ). At the POEM station, the comparison of the temperature at $2 \mathrm{~m}$ below the surface (Fig. 3 $\mathrm{F}$ ) shows an excellent ability of the model to reproduce temperature changes at this location, with a bias of $-0.14^{\circ} \mathrm{C}$ and a correlation of $0.98(\mathrm{p}<0.01)$. The observed and measured salinities (Fig. $3 \mathrm{G}$ ) were generally larger than 36. Only two events, in early October 2010 and mid-March 2011, had lower salinities. The model is very good at representing the timing of salinity drops but tends to predict smaller decreases (correlation of 0.67 and bias of -0.03).

\subsubsection{Glider}

In this section, the fields measured by the glider southwest of the shelf (Fig. 1) are compared to the simulated fields (at the nearest model grid point and time step). Figure 4 shows the depth-averaged current calculated between successive surface returns of the glider at two different times. For the first transect (Fig. 4A), conducted during the easterly storm on 14-15 


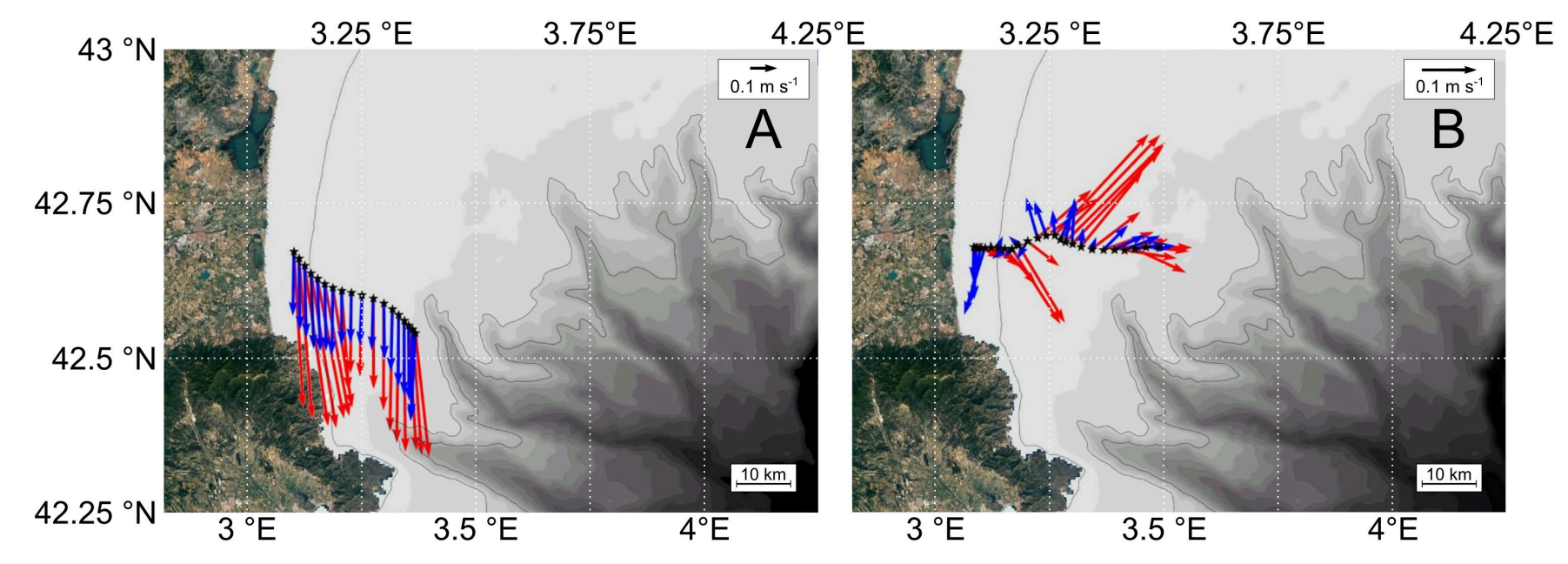

Figure 4: Depth-averaged currents from the simulation (blue) and deduced from the glider trajectory (red) during transects performed between 14 and 15 March 2011 (A) and between 19 and 20 March 2011 (B).

March, a southward alongshore current was measured with velocities between 0.30 and 0.60 $\mathrm{m} \mathrm{s}^{-1}$. The model underestimates these intensities, with values below $0.30 \mathrm{~m} \mathrm{~s}^{-1}$, but the orientation of the currents is similar to that observed. During the second transect, carried out in the low wind period of 19-20 March, a current velocity of less than $0.30 \mathrm{~m} \mathrm{~s}^{-1}$ and a change in current orientation along the glider path, with south-eastward, north-eastward and eastward currents, were measured (Fig. 4B ). The intensity of the simulated currents along this section is still lower than that observed. Nevertheless, the alternating orientation of the currents is well reproduced by the model.

Comparing the Hovmöller diagrams of the observed and simulated temperature (Fig. 5) over the entire glider path shows that the temperature varied between 10 and $15^{\circ} \mathrm{C}$. The thermal characteristics of the water masses sampled during the deployment can be divided into two parts, corresponding to March and April 2011,in which the water temperature was below and above $13{ }^{\circ} \mathrm{C}$, respectively. Despite colder simulated temperatures, the model is consistent with the observations over the two periods. The presence of cold water on the continental shelf between 10 and 17 March is also remarkable, both from the observations and from the model. The salinity of the simulated and observed waters (Fig. 5) was between 37 and 38.5 over the entire glider path. The period can be divided into three sub-periods regarding the salinity: a first marked by homogenization of the water column and water salinity higher than 

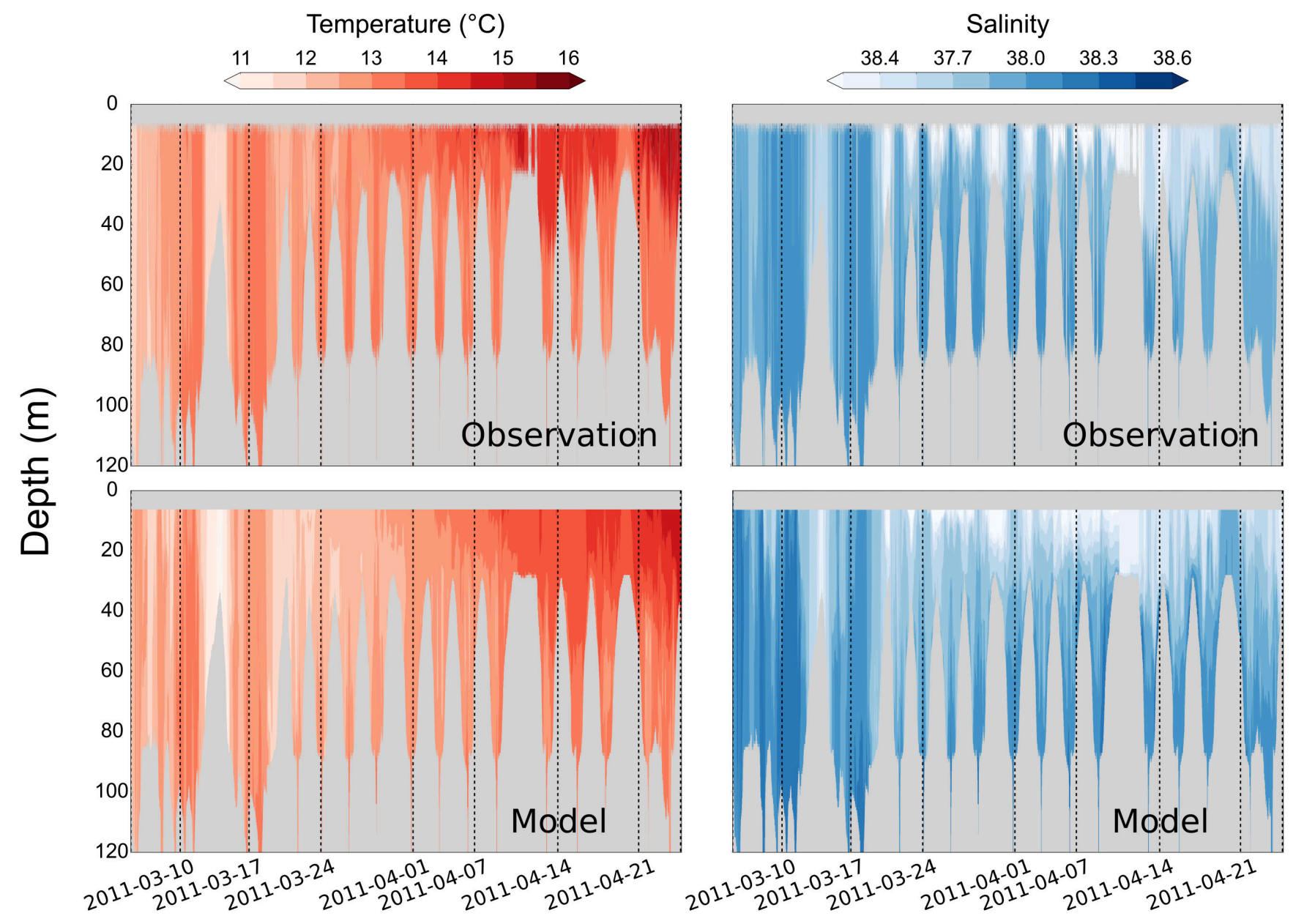

Figure 5: Hovmöller diagrams of the measured and simulated temperature (left) and salinity (right), along the glider path (between 3 March and 28 April 2011). Note that the glider performed successive transects between the coast and the shelf edge (30 km apart) as indicated by the bottom depth in grey.

38 in the first half of March, a second with a decrease in salinity with surface values lower than 38 until mid-April, and a third with another increase in salinity. Although the model shows lower salinity than the observations during the second period, the spatial pattern present in the observations is well represented by the model. By simultaneously studying temperature and salinity, a low-salinity, cold signal can be clearly observed and simulated during the first approach of the glider to the coast (14 March). The good spatio-temporal representation of this phenomenon is to be noticed, despite the underestimation of temperature and salinity by the model.

During the multiple round trips made thereafter between the Lacaze-Duthiers canyon head 
and the coast, an alternation between colder $\left(\mathrm{T} \leq 13^{\circ} \mathrm{C}\right)$ and fresher $(\mathrm{S} \leq 37.4)$ waters at the coast, and warmer $\left(\mathrm{T} \geq 13^{\circ} \mathrm{C}\right)$ and saltier $(\mathrm{S} \geq 38)$ water masses along the shelf break, was observed. This pattern was present with a bias similar to that observed previously. The defects in temperature and salinity in the model also result in a higher density than in the observations. At the beginning of the transect (from 3 to 10 March), the density anomaly in the simulation exceeds $28.95 \mathrm{~kg} \mathrm{~m}^{-3}$, while it is between 28.85 and $28.9 \mathrm{~kg} \mathrm{~m}^{-3}$ in the observations

\subsection{Cap de Creus Canyon}

\subsubsection{Fixed moorings}
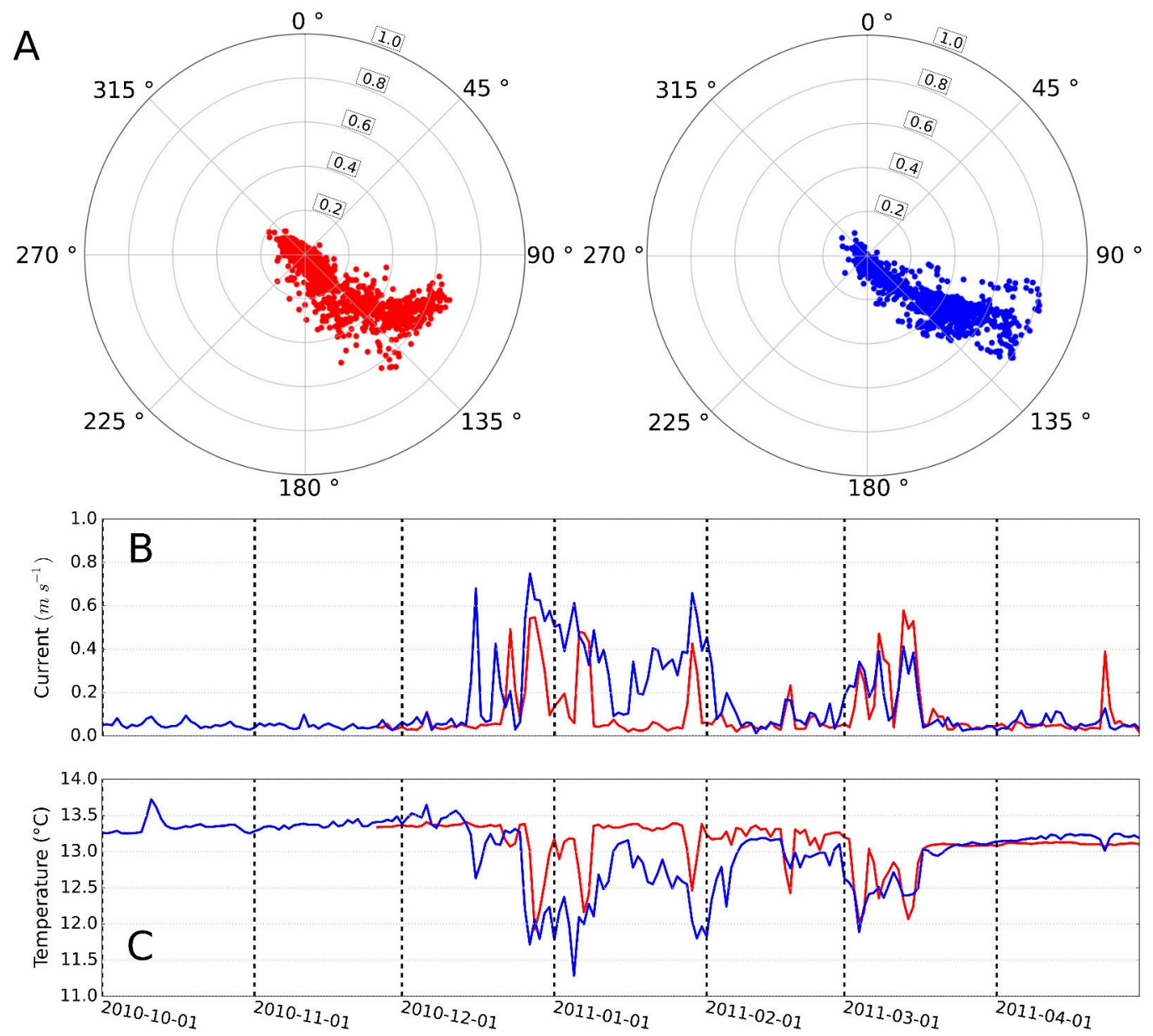

Figure 6: (A) Polar plots of the daily averaged near-bottom currents (in $\mathrm{m} \mathrm{s}^{-1}$ ) at the CCC head $(300 \mathrm{~m})$. Observations (left) and simulation (right). (B) Temporal evolution of daily averaged bottom current and (C) of temperature in the CCC head. Observations are in red and simulation in blue.

Among the moorings located in the CCC, only the mooring at $300 \mathrm{~m}$ at the canyon head 
axis (CH, Fig. 1) was present throughout the winter period. The polar plots of the observed and simulated near-bottom currents (Fig. 6A) show similar characteristics. In both cases,

currents weaker than $0.40 \mathrm{~m} \mathrm{~s}^{-1}$ were directed south-eastwards while more intense currents $(\geq$ $0.40 \mathrm{~m} \mathrm{~s}^{-1}$ ) were directed eastwards/south-eastwards. Their time evolution (Fig. 6B) shows that their intensities in the simulation exceeded $0.60 \mathrm{~m} \mathrm{~s}^{-1}$ during several episodes (between mid-December 2010 and mid-March 2011) while, outside these periods, currents were usually less than $0.10 \mathrm{~m} \mathrm{~s}^{-1}$. The simulation overestimates the intensity of these episodes during the first half of winter (December 2010 to January 2011), a bias of $0.15 \mathrm{~m} \mathrm{~s}^{-1}$ and a correlation of 0.53 being obtained. On the other hand, in the latter part of the winter (February - April 2011), the model is closer to observations, with a bias of $-0.01 \mathrm{~m} \mathrm{~s}^{-1}$ and a correlation of 0.69 .

The time evolution of the measured temperature (Fig. 6C) shows values between 13.25 and $13.5^{\circ} \mathrm{C}$ at the beginning of winter. During the winter, several cooling events concomitant with the increasing currents were observed. The first and most intense event took place in late December/early January $\left(-2^{\circ} \mathrm{C}\right)$. The second one, during the first half of March, was characterized by a succession of temperature drops to below $12.5^{\circ} \mathrm{C}$. Between these two major episodes, several shorter cooling episodes were observed (notably in late January and midFebruary). A comparison with the simulation results shows that, over the entire period, the modelled temperature was lower than the observed temperature. At the beginning of winter, temperatures were similar but, from the first temperature drop (end of December), water masses did not recover the temperatures of 13.25 to $13.5^{\circ} \mathrm{C}$ between cold episodes in the model. On the other hand, the simulation adequately represented the succession of cold episodes of this winter and, in particular, the last one, occurring in March. Statistically, these comparisons result in a bias of $0.22^{\circ} \mathrm{C}$ and a correlation of 0.51 for the whole period.

The Hovmöller diagram of the current measured at mooring SF1, located on the southern flank of the CCC (Fig. 1), shows a succession of 4 events when the current intensity was greater than $0.40 \mathrm{~m} \mathrm{~s}^{-1}$ (Fig. 7A). Two of those episodes exceeded $0.70 \mathrm{~m} \mathrm{~s}^{-1}$ (between 13 and 17 March 2011). This sequence of events and the intensity of the currents are well reproduced by the model (Fig. 7B). At depths of $175 \mathrm{~m}, 215 \mathrm{~m}$ and $280 \mathrm{~m}$, the current intensity bias 

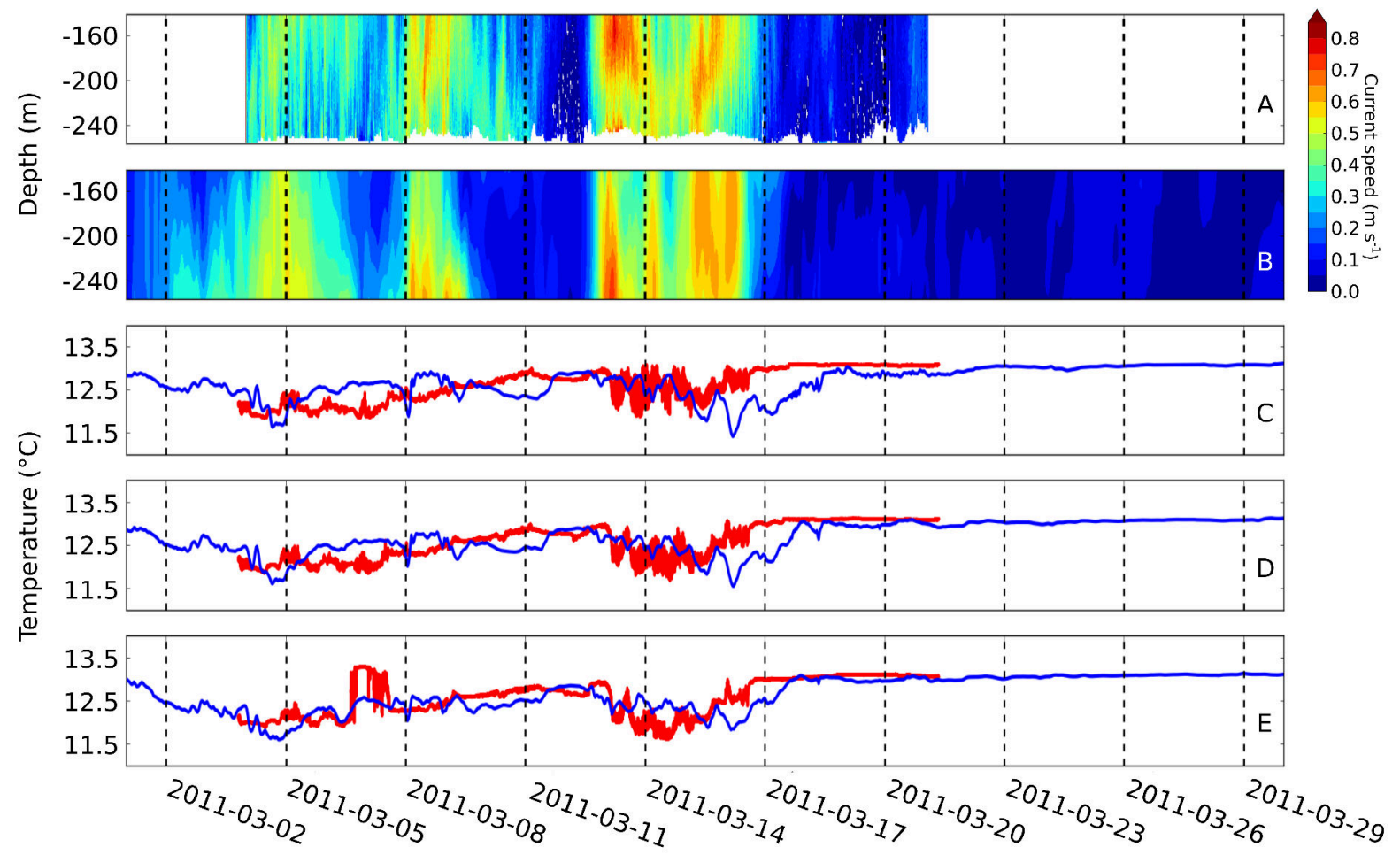

Figure 7: Time series over March 2011 of the current and temperature at the SF1 mooring, located at a depth of $290 \mathrm{~m}$ on the southern flank of the CCC. Hovmöller diagrams of observed (A) and simulated (B) currents. Observed (red) and simulated (blue) temperature at 3 depths: $175 \mathrm{~m}(\mathrm{C}), 215 \mathrm{~m}(\mathrm{D})$ and $280 \mathrm{~m}(\mathrm{E})$.

never exceeds $0.05 \mathrm{~m} \mathrm{~s}^{-1}$ and the correlation is always strong, with values of $0.84,0.83$ and 0.76 (at depths $175 \mathrm{~m}, 215 \mathrm{~m}$ and $280 \mathrm{~m}$, respectively). Regarding temperature, the bias does not exceed $0.08^{\circ} \mathrm{C}$ at the 3 observed depths (Figs. 7C, 7D and 7E). On the other hand, the correlation is highly variable. It is low (0.2) at $175 \mathrm{~m}$ depth, acceptable (0.45) at $215 \mathrm{~m}$ depth and high (0.67) at $280 \mathrm{~m}$. Like the first temporary mooring, the second, SF2 (Fig. 8), shows a series of intense current events. These currents at this mooring were even more intense than at SF1, exceeding $0.80 \mathrm{~m} \mathrm{~s}^{-1}$, during the third episode (14 March). The model does not reproduce these extreme values, and the modelled current does not exceed $0.60 \mathrm{~m} \mathrm{~s}^{-1}$ during the most intense episode.

Over the entire period, the bias is $0.10 \mathrm{~m} \mathrm{~s}^{-1}$. However, the simulation reproduces the timing of these events since, at the 3 fixed depths of 250,290 and $355 \mathrm{~m}$, the correlation is remarkably strong $(0.89,0.88$ and 0.75 , respectively). The time evolution of the temperature (Figs. $8 \mathrm{C}$, 8D and $8 \mathrm{E}$ ) shows that the model reproduces the general pattern found for the observations. 

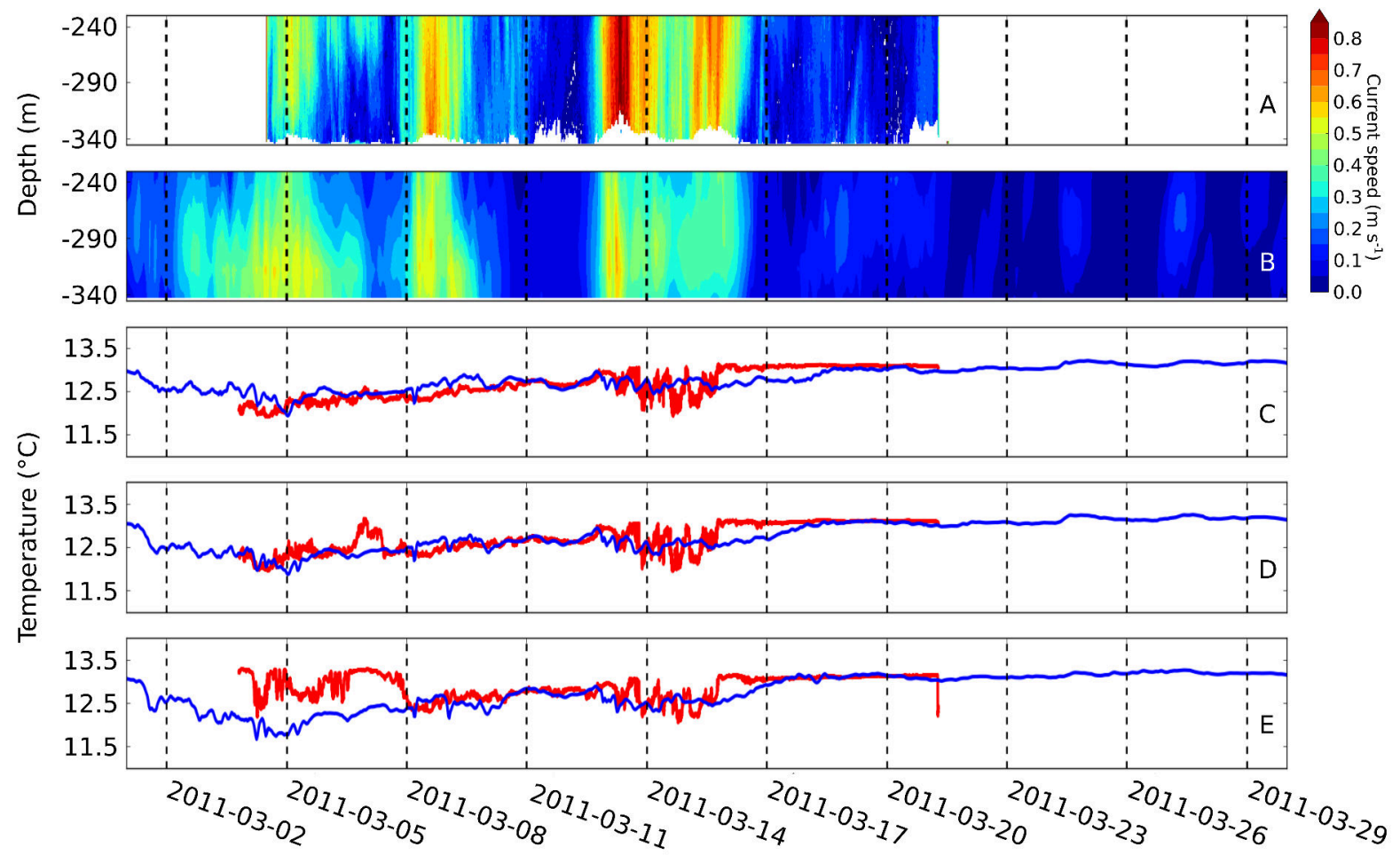

Figure 8: Time series over March 2011 of the current and temperature at the SF2 mooring located at $365 \mathrm{~m}$ on the southern flank of the CCC. Hovmöller diagrams of observed (A) and simulated (B) currents. Observed (red) and simulated (blue) temperature at 3 depths: $250 \mathrm{~m}(\mathrm{C}), 290 \mathrm{~m}$ (D) and $355 \mathrm{~m}(\mathrm{E})$.

However, the statistics calculated at the 3 available depths are, as for SF1, heterogeneous on the vertical. At the deepest point $(355 \mathrm{~m})$ the bias and correlation are $0.27^{\circ} \mathrm{C}$ and 0.24 respectively while, at shallower levels $(250 \mathrm{~m}$ and $290 \mathrm{~m})$ they are better, with biases of 0.02 and $0.07^{\circ} \mathrm{C}$, respectively, and correlations above 0.7 in both cases.

\subsubsection{Hydrographic section}

In Figure 9, the temperatures observed using CTD profiles during the easterly storm documented by the CASCADE experiment in the CCC are superimposed on the model vertical section along the path followed by the vessel. The first three CTD profiles, carried out in the upper part of the canyon, reveal the presence of a cold, low-salinity water mass (with temperatures below $11^{\circ} \mathrm{C}$, salinity less than 37.7 , not shown here), which is well reproduced by the model (same characteristics). On the southern slope of the canyon, down to a depth of about $300 \mathrm{~m}$ (next 4 profiles), a $100 \mathrm{~m}$ thick tongue of cold, low-salinity water extends along 


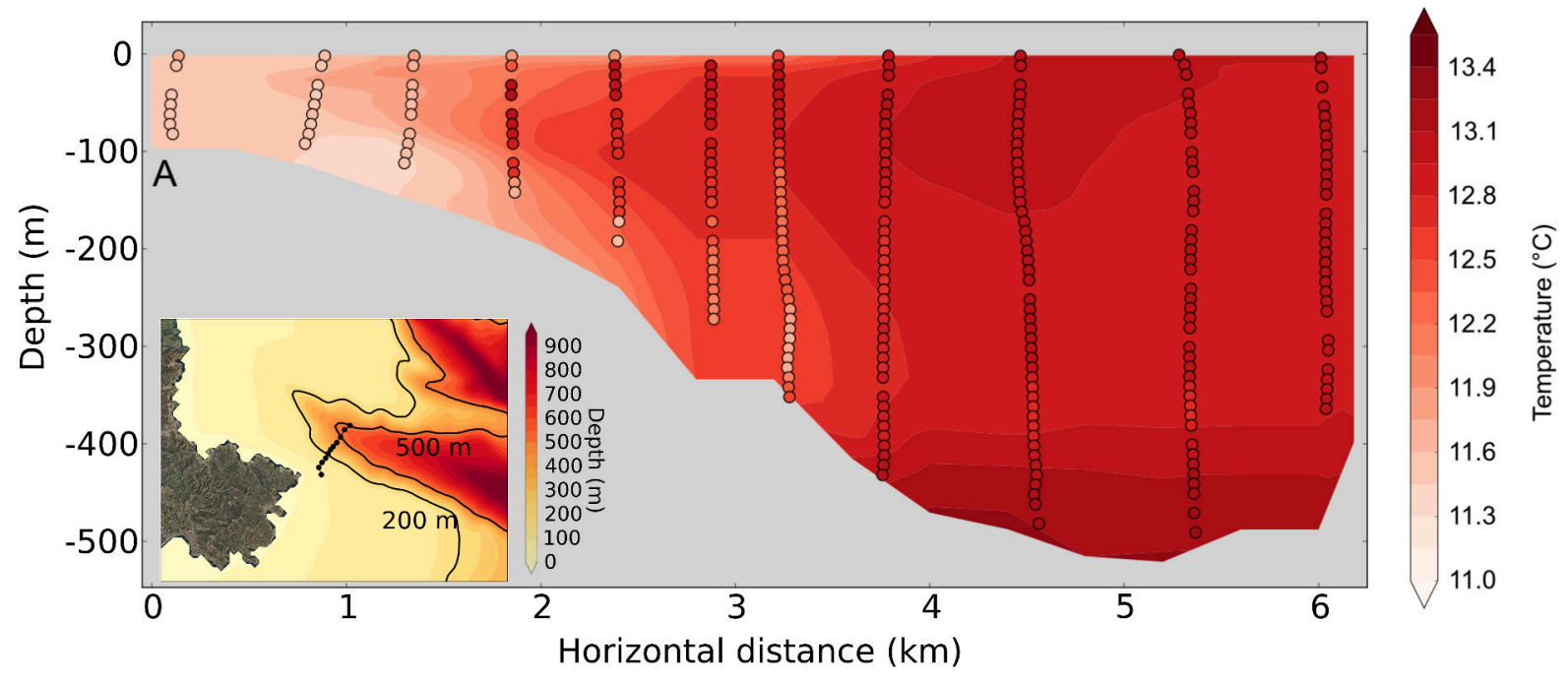

Figure 9: (A) Simulated temperature for 14 March 2011 along the hydrographic section crossing the southern Cap de Creus canyon flank. Observations (one point out of 10) are represented by circles superimposed on the model results. (B) Position of the CTD casts superimposed on the model bathymetry.

the bottom, with a salinity lower than 37.8 and a temperature lower than $12{ }^{\circ} \mathrm{C}$. Above, the salinity of this water mass is greater than 38 and the temperature higher than $12.5^{\circ} \mathrm{C}$. The cold, less salty water tongue is present in the model results but, overall, the spatial extent is smaller, and the contrast with its environment weaker. The last profiles of the CTD transect were located in the axial part and lower northern flank of the canyon (depth up to $500 \mathrm{~m}$ ). In the first 350 meters, observations and simulated fields show a relatively well-mixed water column with temperatures between 12.8 and $13^{\circ} \mathrm{C}$ and salinities between 37.9 and 38.1 , over a bottom layer characterized by a strong vertical gradient. Observations and simulation show salinities reaching 38.5 and temperatures above $13.2^{\circ} \mathrm{C}$ in this $150 \mathrm{~m}$ thick bottom layer. 


\section{Results}

In this section, the numerical outputs are used to study (1) the impact of GoL coastal circulation induced by the different wind regimes on the residence times of water masses most exposed to the Rhône River supply, and (2) the spatial and temporal characteristics of water transport through the complex south-western tip region of the GoL.

\subsection{Residence times near the mouth of the Rhône River}

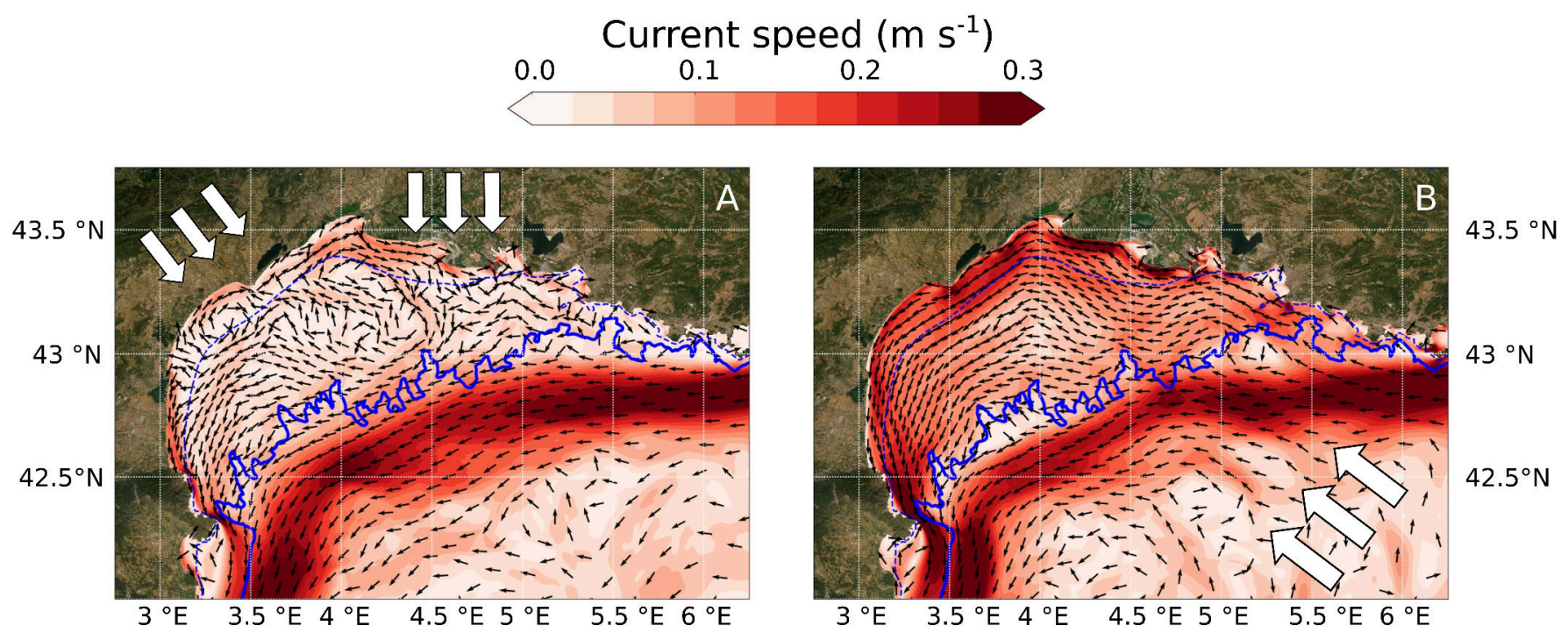

Figure 10: Currents averaged over depth (200 $\mathrm{m}$ or the water column if shallower), and over 3 wind episodes: (A) northerly winds, 13 - 21 October, 18 - 26 January, 18 - 28 February and (B) easterly winds, 6 - 12 October, 5 - 9 January, 12 - 16 March. The $200 \mathrm{~m}$ isobath is represented in blue.

Figure 10 presents the depth-averaged currents averaged over 3 episodes of the prevailing northerly wind (A) and of easterly wind (B), which were among the most intense of the period studied. Easterly winds generated a south-westward circulation over the entire GoL. The current was intensified along the coast and at the southwestern tip of the continental shelf due to the topographic constraint of the continental shelf narrowing. This is in agreement with the study by Ulses et al. (2008a). During northerly winds, the current pattern was more complicated because the average represented here resulted from an overlap of different nuances of the Mistral/Tramontane wind system that generated opposite currents in some subregions, as shown by Estournel et al. (2003). Here, two along-shore circulations with opposite 
455 the continental shelf and off Marseille, anticyclonic circulations were present as schematized in Fig. 11.

\subsubsection{Spatial distribution of particles according to wind direction}

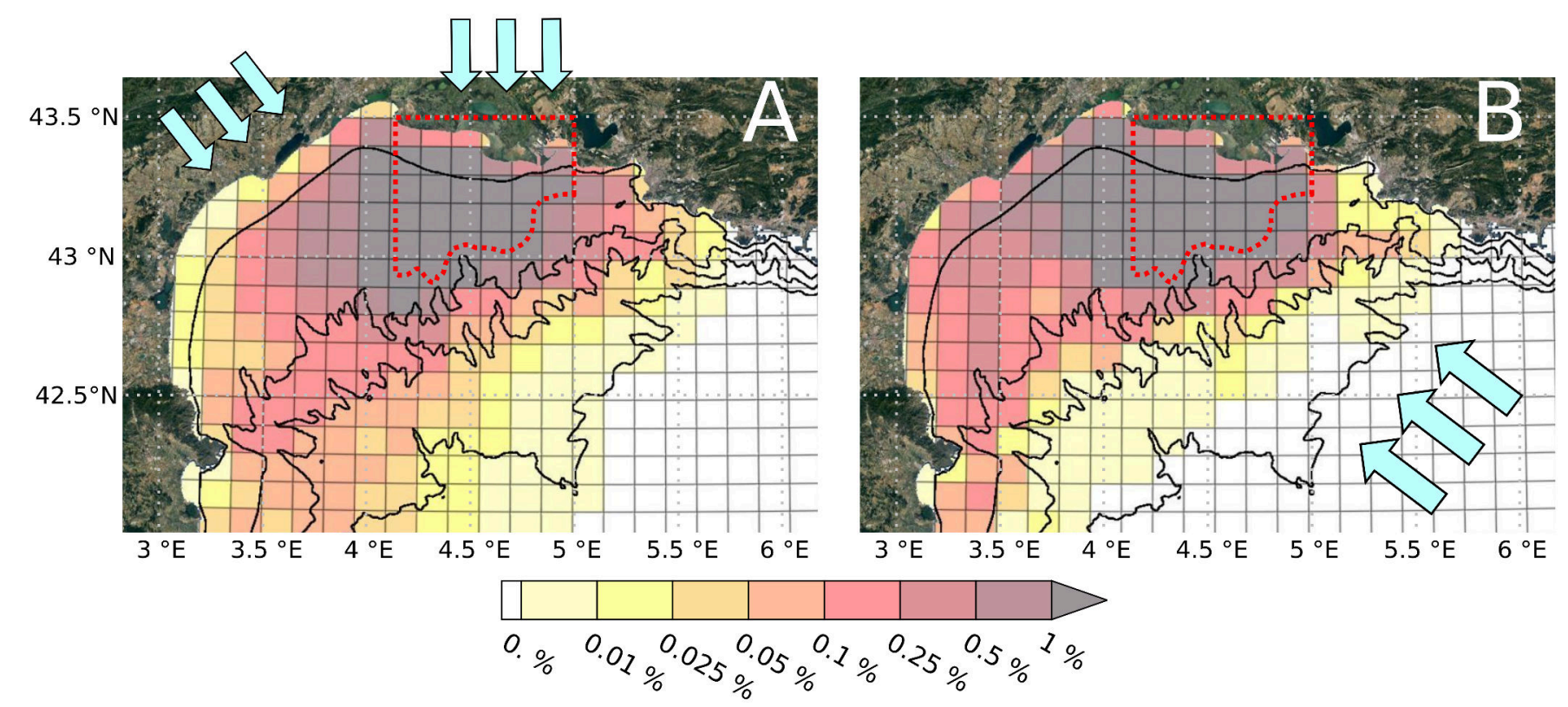

Figure 11: Proportion of Lagrangian particles present at the end of the northerly (A) and easterly (B) wind episodes (defined in the caption of Fig. 10). The blue arrows represent the wind direction, the red dotted box is the area where particles were released and the black lines correspond to the 50, 200, 1000 and $2000 \mathrm{~m}$ isobaths.

The simulation of Lagrangian particle trajectories was used to study the impact of strong wind (i.e. daily averaged intensity at MesuRho greater than $8 \mathrm{~m} \mathrm{~s}^{-1}$ ) on the displacement of water masses. Particles were released at the beginning of strong wind events in an area located in front of the Rhône river mouth (red box on Figure 11, see details in section 2.1.3.1). Two maps (Figure 11) were obtained, one for each regime, representing the percentages of total released particles present at the end of the wind episodes. First of all, irrespective of the wind regime, at the scale of an episode, the duration of which varied between 2 and about 10 days, the majority of the particles remained on the GoL continental shelf. Easterly wind episodes caused the waters initially close to the Rhône to move westward along the coast with percentages per box that were, at most, between $0.25 \%$ and $0.5 \%$. In contrast, northerly wind episodes 
generated a low particle supply along the coast (maximum values lower than $0.05 \%$ per box), the particles being mainly advected towards the outer shelf and the slope. These observations support the above conclusions on wind-induced circulation. Easterly winds generate an intense along-shore current and downwelling conditions. In this case, particles tend to follow the French and Spanish coasts. In contrast, northerly winds generate more complex currents on the continental shelf and, along its northern part, upwelling conditions. The direct consequence is that some particles stagnate in the release area while others approach the slope and come under the influence of the Northern Current, which explains the relatively high percentages in the boxes between the 200 and $1000 \mathrm{~m}$ isobaths in the western part of the domain. These distributions were made at the scale of the wind event. The next section addresses the residence time on the GoL shelf at the seasonal scale.

\subsubsection{Time evolution of the residence time near the mouth of the Rhône River}

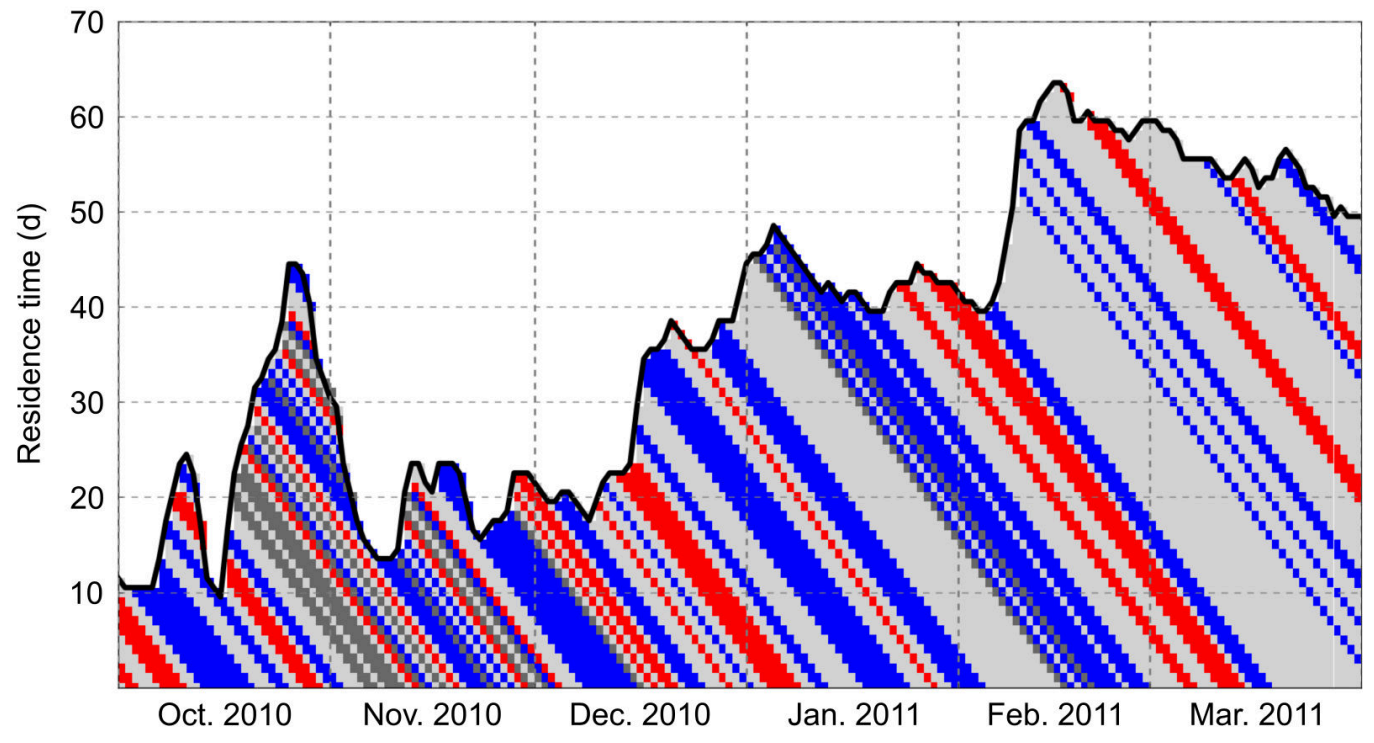

Figure 12: Time evolution of residence time (day) (black line). The succession of daily averaged winds (simulated at MesuRho, Fig. 1) that influenced the movement of the particles is represented under the line by coloured pixels: northerly (respectively easterly) winds stronger than $8 \mathrm{~m} \mathrm{~s}^{-1}$ are shown in blue (respectively red), winds from other directions stronger than $8 \mathrm{~m} \mathrm{~s}^{-1}$ are in dark grey, and winds lower than $8 \mathrm{~m} \mathrm{~s}^{-1}$ in light grey.

Figure 12 plots the residence time of the water masses recently influenced by the Rhône River versus time (see section 2.1.3.2). The colours under the black curve provide information on the 
succession of winds having influenced the movement of the water mass during its presence on the shelf. For example, for all particles released on 1 December 2010, the black curve indicates that 21 days were required for $50 \%$ of the particles to be exported off the shelf. The succession of colours on the vertical (from bottom to top) indicates that this period is composed of 6 days with winds either having speeds lower than $8 \mathrm{~m} \mathrm{~s}^{-1}$ or changing direction from one day to the next, then a second period of 8 days with a northerly wind of velocity higher than $8 \mathrm{~m} \mathrm{~s}^{-1}$ and, to finish, a period of 7 days with an alternation of strong easterly winds and weak winds. Residence time on the shelf is very variable, ranging from about 15 days to more than 60 days. This duration is shorter during autumn and early winter (30 days on average from October to January) than during the rest of the simulation (55 days on average from February to April).

\subsection{Variability of export of Gulf of Lion coastal water around the Cap de Creus}

Here, the spatial and temporal variability of water export in the Cap de Creus region in the south-western part of the shelf, a key area for export, is examined. For this purpose, different sections have been defined around the CCC (Fig. 13A). Net water transport (total, 0-200 m and 200 m-bottom) through these sections was calculated over autumn (from 21 September to 21 December) and winter (from 21 December to 21 March). In addition to the time series of water transport, the daily mean of the surface heat flux, averaged over the GoL continental shelf, and the salinity in the CCC are also shown in Figure 14.

\section{Whole period}

The total net water transport leaving the continental shelf through the canyon (section B-E) and the coastal strip to the west of this canyon (section A-B) was $0.20 \mathrm{~Sv}$. The coastal strip A-B represented $65 \%$ of the transport. Nearly two-thirds of the net amount of water leaving the shelf corresponded to along-shore transport (0.11 Sv, AC green section); the rest originated from the outer shelf and entered through the canyon head (0.03 Sv) and its northern flank $(0.05 \mathrm{~Sv})$. The transport through the southern flank of the canyon was lower than $0.02 \mathrm{~Sv}$ on average.

The comparison between autumn and winter shows that the GoL's export during winter was $50 \%$ higher than during autumn. More precisely, the outflow from the continental shelf 

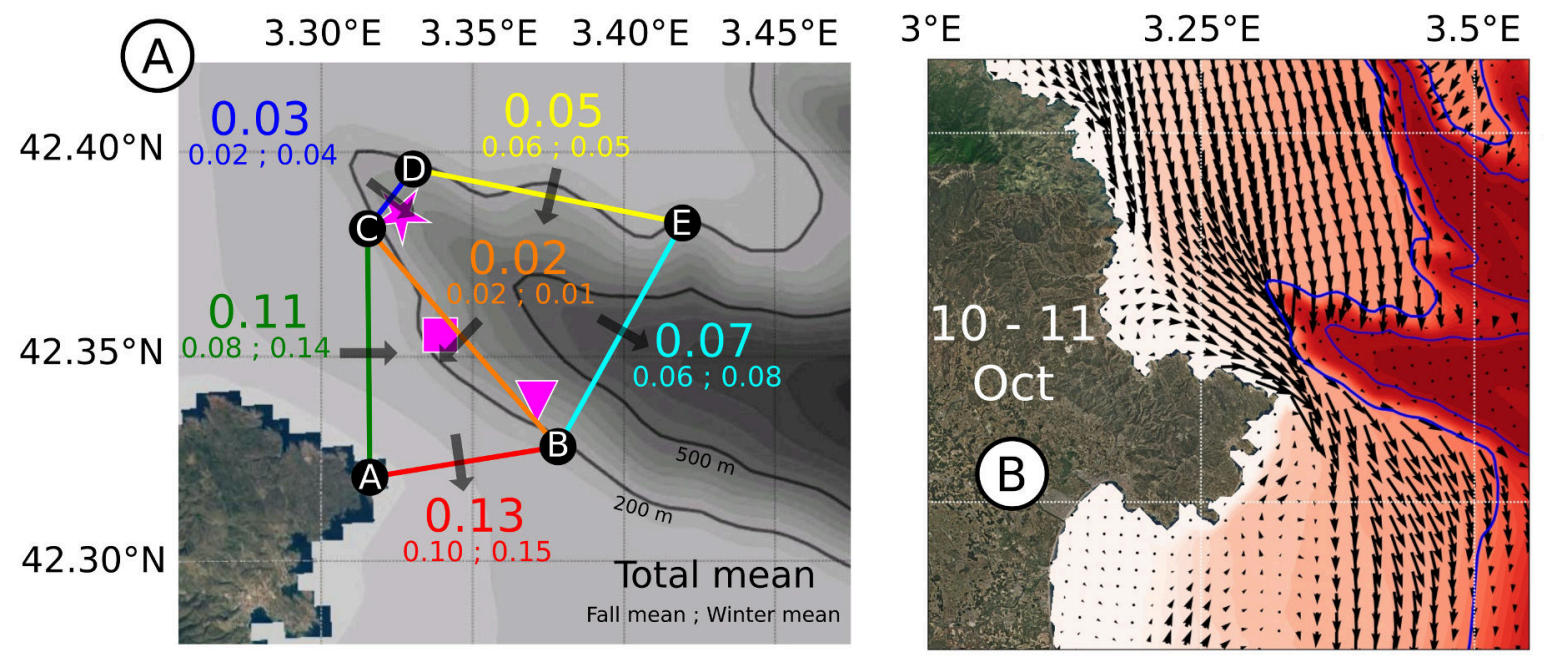

$42.5^{\circ} \mathrm{N}$
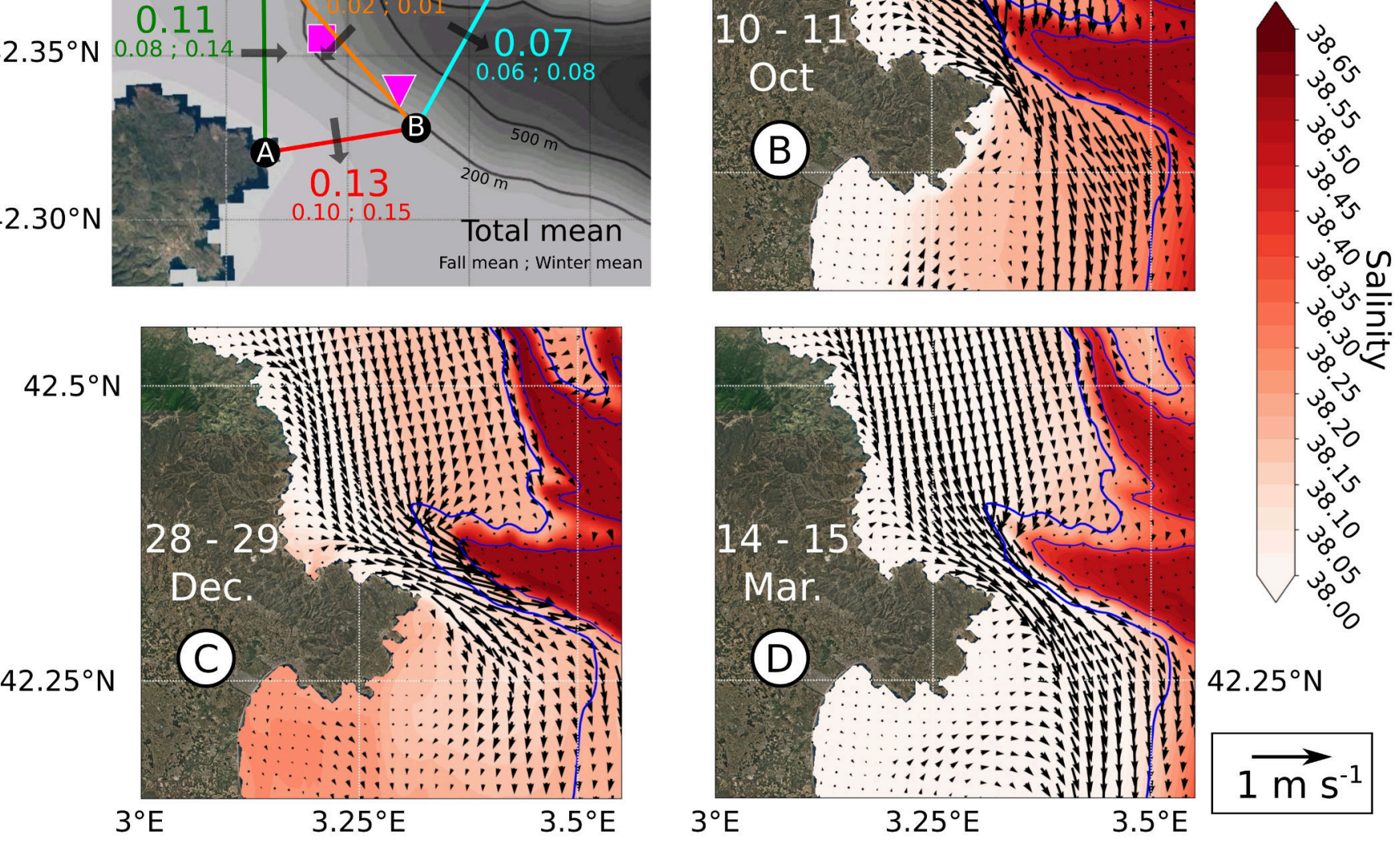

Figure 13: (A) mean net water transport (Sv) indicated for different sections in the Cap de Creus region over the entire period (top), autumn 2010 (bottom left) and winter 2010-2011 (bottom right). The pink star, square and triangle indicate the positions of $\mathrm{CH}, \mathrm{SF} 1$ and SF2 moorings (respectively). (B), (C), (D) fields of bottom currents and salinity averaged over 10-11 October 2010, 28-29 December 2010 and 14-15 March 2011, respectively.

along the coast (section A-B) was 50\% larger during winter than during autumn. The winter increase observed on the coastal section A-B was also found on section $\mathrm{A}-\mathrm{C}$ and at the canyon head (section C-D). In contrast, the export through the northern flank (D-E) was reduced in winter. The distinction between the two seasons is also visible in the temporal evolution of the hydrological parameters at the bottom of the CCC (Fig. 14C). Before mid-December, no clear salinity or density variation signal was visible at the bottom. After mid-December and the marked December heat losses (Fig. 14A), salinity and density at this depth underwent strong 


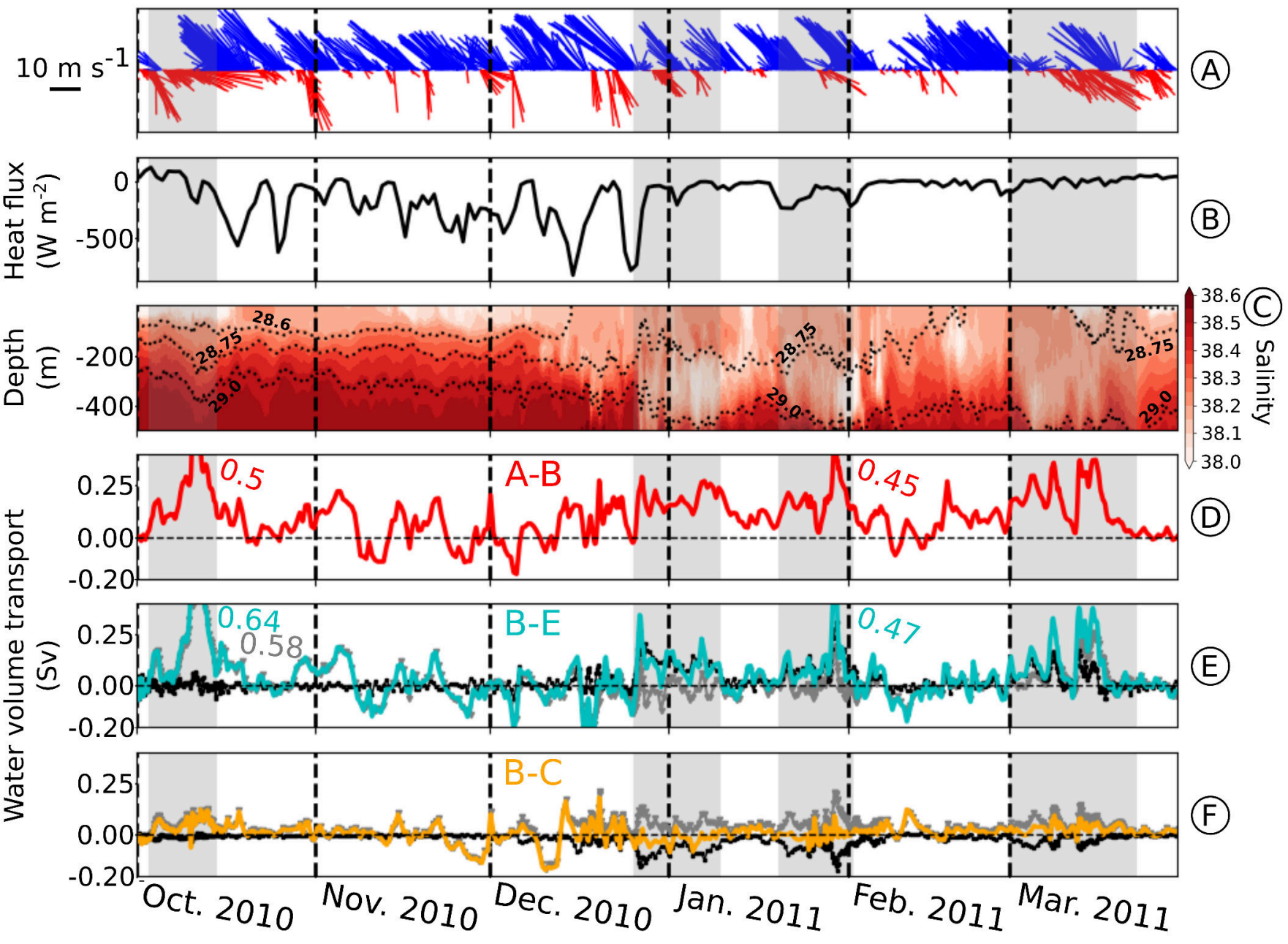

Figure 14: Time evolution of (A) the wind intensity and direction (easterly in red and northerly in blue; ECMWF outputs) at POEM station (Fig. 1); (B) total heat flux averaged over the GoL continental shelf; (C ) salinity with density contours at $500 \mathrm{~m}$ on the southern flank of the CCC; (D), (E) and (F) simulated water transport (Sv) for the red A-B, cyan B-E, and orange B-C sections (shown in Fig. 13), respectively, (positive values correspond to the orientation of the arrows in Fig. 13A). The coloured line corresponds to the total transport, the grey line to the water transport over the upper $200 \mathrm{~m}$ and the black line to the transport from $200 \mathrm{~m}$ to the bottom.

variations until the end of the simulation.

Figures $14 \mathrm{D}, 14 \mathrm{E}$ and $14 \mathrm{~F}$ show the impact of intense wind events on the magnitude and vertical structure of the export. The temporal variability of the water transport is significant, with values generally less than $0.5 \mathrm{~Sv}$, regardless of the section and direction. Over the period studied, four export episodes (highlighted by grey rectangles in Fig. 14) were considered re- 
markable and are detailed in the following.

\section{Period 1 (3-15 October 2010)}

The first period corresponds to the most intense export event of the entire study, with water transport exceeding 0.5 Sv on each of the GoL exit sections (A-B and B-E). During this event, the transport through B-E was mainly restricted to the 0-200 m layer. This ten-day period was marked by an alternation of winds: easterly, northerly and easterly again. The two easterly wind episodes had daily mean wind velocities greater than $12.5 \mathrm{~m} \mathrm{~s}^{-1}$, which generated an intensification of the coastal current, as shown in Figure 10. Because of the strong stratification during this season, the export mostly concerned the upper layer. However, Figure $14 \mathrm{C}$ shows a clear low salinity signature down to a depth of $400 \mathrm{~m}$, corresponding to the coastal water downwelling characteristic of these strong easterly wind events (Ulses et al., 2008a). Figure 13B shows the current along the bottom averaged over the two days corresponding to the maximum of the storm. The acceleration of the flow is clear at the narrowing of the Cap de Creus coastal strip. The water from the shelf enters the canyon perpendicular to its northern flank down to depths of 300-400 m. Farther downstream, the light water vein is no longer visible as it flows at intermediate depth. On the southern flank, the current flows along the isobaths not exceeding 200m depth. This indicates the presence of downwelling when the current enters the canyon across its northern flank, followed by a rise of the light water mass inside the canyon to stabilize at its equilibrium level along the southern flank.

\section{Period 2 (26 December - 10 January)}

The second strong export period was marked by intense water transport through section A-C, with a mean value of $0.20 \mathrm{~Sv}$ corresponding to $70 \%$ of the water leaving the GoL shelf (not shown). The other part of the exported water flowed through the canyon head (20\%) and its northern flank (10\%). The mean water volume transport leaving the shelf through the coastal strip (0.18 Sv for section A-B) was greater than that through the canyon $(0.11 \mathrm{~Sv}$ for section B-

E). On the other hand, this period was the first one with transport through B-E in the bottom 
layer $(0.13 \mathrm{~Sv})$ that was greater than in the upper layer $(-0.01 \mathrm{~Sv})$ (Fig. $14 \mathrm{E})$. On sections B-E and $\mathrm{B}-\mathrm{C}$, the water transport was vertically sheared with bottom waters entering the canyon through B-C and thus contributing to the export through B-E, while surface transport was directed in the opposite direction (Fig. $14 \mathrm{E}$ and $14 \mathrm{~F}$ ).

This key period was characterized by a temperature (Fig. 6) and salinity (Fig. 14C) drop and can be considered as a first shallow, dense shelf water cascading event. It was preceded by strong northerly winds and strong heat fluxes (several days with a mean heat loss higher than $600 \mathrm{~W} \mathrm{~m}^{-2}$ ) that caused cooling and densification of the shelf waters. The beginning of the cascading corresponded to the peak of heat fluxes. A new increase in export (around January 5), clearly visible on the measured current at the canyon head (Fig. 6), would be linked to an easterly wind (Fig. 2), which would enhance the advection of the dense water mass towards the southwest.

Figure $13 \mathrm{C}$ shows the bottom current averaged over 2 days, 28 and 29 December, chosen for the reasonable agreement between model and observations (Fig. 6). Around the canyon head, the incidence of current in the canyon was almost normal to the isobaths. In contrast to the October storm, the current along the southern flank clearly entered the canyon with an angle of incidence that gradually decreased towards the southeast. Dense water did not penetrate significantly below $500 \mathrm{~m}$ depth. As with other important export periods, the current was strong in the coastal strip along the Cap de Creus promontory.

\section{Period 3 (20 January - 2 February)}

In the second half of January, a new northerly wind episode occurred with relatively low heat losses compared to December (Fig. 14A and 14B). Then, a short-lived moderate easterly wind $\left(\leq 10 \mathrm{~m} \mathrm{~s}^{-1}\right)$ induced peaks of export through all the sections in the last days of January and

rapid variations of density in the canyon (Fig. 14C). Export had the same spatial characteristics as those of the previous period. For the section corresponding to the southern flank of the canyon (B-C), the water transport in the bottom layer was of the same order of magnitude as in the upper layer but in the opposite direction (Fig. $14 \mathrm{~F}$ ). In the cross-canyon section (B-E), the 
bottom layer was the main export pathway (90\% of the total transport of $0.11 \mathrm{~Sv}$, Fig. $14 \mathrm{E}$ ). general pattern is quite consistent with the interpretation of observations proposed by Martín et al. (2013) in their Fig. 12 .

\section{Synthesis}

Table 1 summarises the volumes of water exported from the GoL shelf during the four periods analysed previously and during the whole period from late September to late March. The 
CASCADE period (period 4) illustrates the strong impact of easterly winds since $1 / 3$ of the cumulated export over 23 days occurred during the 5 days of this wind regime, i.e. $20 \%$ of the period. The October storm represented $60 \%$ of the export of the whole autumn. Whatever the 610 period, it appears that the coastal section (A-B) was the main export pathway. Only during major easterly storms did similar volumes flow through the two sections (differences $<15 \%$ ). Besides, during the first period, only $3 \%$ of the water $\left(6 \mathrm{~km}^{3}\right)$ was exported to depths greater than $200 \mathrm{~m}$ in the canyon. On the other hand, during the three remarkable winter periods, significant volumes of shelf water were transported into the canyon below $200 \mathrm{~m}$. Period 2 615 presented the largest volume transported in the bottom layer $\left(153 \mathrm{~km}^{3}\right)$. Period 3 showed similar behaviour with a lower bottom export $\left(111 \mathrm{~km}^{3}\right)$. Finally, the CASCADE period was the one during which the volume of water exported below $200 \mathrm{~m}$ was the lowest, with $84 \mathrm{~km}^{3}$, $29 \mathrm{~km}^{3}$ of which left during the easterly storm. 
Table 1: Net volume of water $\left(\mathrm{km}^{3}\right)$ that flowed from north to south through the sections A-B and B-E during the periods highlighted in Figure 14.

\begin{tabular}{|c|c|c|c|c|}
\hline Period (duration in days) & $\begin{array}{l}\text { section } A-B \\
0-200 \mathrm{~m}\end{array}$ & $\begin{array}{c}\text { section B-E } \\
\text { surface-bottom } \\
\text { (200 m - bottom) }\end{array}$ & $\begin{array}{l}\text { shelf / total } \\
\text { (in } \%)\end{array}$ & $\begin{array}{c}\text { canyon } \\
\text { bottom/total } \\
\text { (in } \%)\end{array}$ \\
\hline $\begin{array}{c}\text { Period } 1 \\
(13 \text { d from } 3 \text { to } 15 \text { October })\end{array}$ & 228 & $219(6)$ & 51 & 3 \\
\hline $\begin{array}{c}\text { Period } 2 \\
\text { (16 d from } 26 \text { December to } 10 \text { January ) }\end{array}$ & 221 & $132(153)$ & 63 & 116 \\
\hline $\begin{array}{c}\text { Period } 3 \\
\text { (14 d from } 20 \text { January to } 2 \text { February) }\end{array}$ & 207 & $123(111)$ & 63 & 90 \\
\hline $\begin{array}{c}\text { Period } 4 \\
(23 \text { d from } 1 \text { to } 23 \text { March })\end{array}$ & 339 & $204(84)$ & 62 & 41 \\
\hline $\begin{array}{l}\text { March easterly storm only } \\
\text { ( } 5 \text { d from } 12 \text { to } 16 \text { March) }\end{array}$ & 92 & $85(29)$ & 52 & 34 \\
\hline Total period (autumn + winter) & 1529 & $731(411)$ & 68 & 56 \\
\hline Autumn & 470 & $277(31)$ & 63 & 11 \\
\hline Winter & 1059 & $454(385)$ & 70 & 85 \\
\hline
\end{tabular}




\section{Discussion}

\subsection{Weaknesses and strengths of the simulation}

We developed and used a 3D model to study the shelf circulation of the GoL and exchanges with the adjacent regions. This study represents one of the rare attempts to evaluate the residence time of shelf waters and shelf-slope exchanges in this region. Most of the previous modelling studies focused on estimating shelf water export and restricted their estimates to storm and/or cascading periods (Ulses et al., 2008a c). Here, we extended the period of export estimation to the whole autumn and winter periods. To refine the assessments, the horizontal resolution of the model grid was increased by a factor of 3 relative to that used in the studies by Ulses et al. (2008a c), for a better representation of the narrow canyons, major pathways of shelf waters towards the deeper parts of the margin. The use of online coupling with a wave model is also an innovation in our study. It allows the integration of waves, and their feedback on currents, into water mass dynamics at high temporal resolution. Comparisons of the simulation of this study with a simulation without waves showed little differences. However, over short periods with storm or cascading events (for the canyon head) it appears that the differences are in favour of the coupled simulation. Even if the differences are not systematically in favour of the coupled simulation, it has been carried out with the aim of coupling hydrodynamics and sediment transport to quantify in a future study the particulate matter export associated with coastal water exports. Wave-current coupling is then necessary to provide a correct representation of the bottom turbulence that governs sediment resuspension.

The detailed comparison between the model results and observations (section 3) shows that the simulation reproduces the major characteristics of hydrology and currents on the inner shelf. Along the northern coast of the GoL, the current over the entire water column was subject to strong, sustained accelerations that were systematically associated with easterly winds (Fig. 2). Moreover, seasonal variations in surface hydrology to the west of the continental shelf are well described while, to the north, the data are partial and located in a strong gradient area, making it difficult to conclude. At the scale of events, the decreases in salinity to the west, linked to the passage of riverine waters, are reproduced. The model also reproduces the 
cross-shore spatial temperature and salinity gradients (colder, fresher inner-shelf water versus warmer, saltier outer-shelf water). The major drawback of the simulation on the shelf concerns the underestimation of the current speed to the west of the continental shelf in March (Figs. 650

3 and (4). Unfortunately, the absence of a long time-series of observations does not allow a possible systematic defect in the representation of intense events. However, it can be noted that this defect does not appear in the northern part of the investigated domain.

In the CCC, the situation is complex, partly due to the high heterogeneity of the bathymetric constraint on the flow. Regarding the seasonal variability at the canyon head, (Fig. 6), the strong contrast observed between autumn, a period with very limited variability of bottom current speeds and temperature, and winter, when currents become more variable and current intensity may increase by an order of magnitude in concordance with temperature drops of more than one Celsius degree, is also reproduced by the model. Zooming in on winter, it is also possible to see, thanks to the temporary instrumented multi-level moorings (Figs. 7, 8), the excellent timing of the model in reproducing these current anomalies, which concern a layer at least $100 \mathrm{~m}$ thick above the bottom. Regarding the magnitude, during the first part of winter, when the density of the shelf waters increased, the simulation gives a current that is too strong and water that is too cold at the canyon head (Fig. 6) while, later, in February / March, the comparison at the different moorings shows much better agreement.

Despite the good performance of the high-resolution model, the weak points of the simulation identified suggest an underestimation of the water export from the GoL limited to the coastal strip during easterly storm events. On the other hand, during the cooling period (end of December - 2 February 2011), the model overestimates water transport in the lower layer. A quantitative comparison of the time integrals of the current at the canyon head mooring given by observations and simulation shows that the latter overestimates by a factor of 2.3 (representing an excess of about $150 \mathrm{~km}^{3}$ if this difference is applied to the transport through the canyon). This result must be moderated, as the model indicates that the mooring would be at the eastern limit of the cascading vein (Fig. 13). It can be noted in Fig. 13C that, during cascading, the current seems to be much more homogeneous on the southern flank of 
675 probably have been possible to assess the uncertainties on transport during this cascading period more precisely.

\subsection{Residence time and export}

Our estimates show that, over the period considered, the functioning of the GoL was globally 680 characterized by a net outflow to the southwest balanced by a net inflow to the centre and east of the shelf. On the eastern and central slope, spatial and temporal variability was strong and was related to two main factors: wind and the Northern Current. In 2010-2011, the frequency of strong winds and the alternation of northerly and easterly winds (Fig. 12) were higher in autumn than in winter. In addition, the position of the Northern Current on the slope was also variable and higher on the slope in autumn than in winter (not shown). This produced an intensification of the exchanges between the outer shelf and the Northern Current in autumn, e.g. along the outer edge of the Rhône plume under northerly wind conditions, whereas in winter the central area of the shelf was more isolated. The combination of these two types (meteorological and oceanic) of forcing explain the lower residence times in autumn for particles initially present in the eastern part of the shelf.

In the southwest, in autumn, the storm of October was a major event at the scale of the season (60\% of the seasonal export). Outside this big event, there was an alternation between import and export periods (Fig. 14), probably depending on complex wind patterns. It, therefore, seems that, in autumn, the presence of strong, long-lasting easterly storms (about ten days here), is a major component of the seasonal export, while shorter storms produce much weaker exports, partly compensated by imports during certain northerly wind episodes.

In winter, the flow is always outgoing to the south-west, due to the increased density of the shelf water (Fig. 14), although this increase was very moderate during the winter of 2010-2011. Such a weak densification of shelf water could be the reason why moderate easterly wind events played a role in triggering or intensifying the weak cascading, as in December and January, by advecting the coastal water mass toward the south-west. This role of the easterly winds over winter 2010-2011 had already been noted byi Rumín-Caparrós et al. (2013). It was also 
highlighted for the autumn-winter of 2003-2004, which, to the first order, is comparable to the period studied here (presence of strong storms and relatively mild winter) (Ulses et al., 2008a). Unfortunately, the export was only quantified over a few days, making any comparison difficult. Nevertheless, it can be noted that an export of $150 \mathrm{~km}^{3}$ was found over 5 days in February 2004, which is of the same order of magnitude as the $177 \mathrm{~km}^{3}$ found here for the 5 days of the March storm.

Our estimates show that, over the entire autumn-winter period, export by the coastal strip of the Cap de Creus dominated (68\% on average, Table 1). This proportion decreased to values close to $50 \%$ during strong easterly storms, as these storms are associated with very high water transport (of the order of $0.5 \mathrm{~Sv}$ ) which cannot exit entirely through the narrow coastal strip and so penetrate into the canyon to a depth of several hundred metres (Ulses et al., 2008c).

In the canyon, water preferentially flowed into the upper layer in autumn, especially during the October storm, and then into the lower layer during the cascading period in January/February (Table 1). Note that, during the March storm, the fraction exported into the lower layer decreased. This was related to the input of light, low salinity water (Fig. 13D) at the surface during the coastal river floods that accompanied this storm. Vertical stratification was then increased, which reduced mixing, increased current shear and thus increased surface export relative to deeper export.

\subsection{Interannual variability of export}

Two winter regimes have been distinguished regarding the characteristics of shelf water export: a first one driven by storms and concerning light shelf water, and a second, for which the waters formed on the shelf are very dense, potentially denser than those of the Western Mediterranean deep basin (Dufau-Julliand, 2004; Palanques et al., 2006; Canals et al., 2006; Ulses et al., 2008a c; Durrieu de Madron et al., 2013; Rumín-Caparrós et al., 2013).

During winter 2010-2011, the density anomaly of the shelf water around $28.9 \mathrm{~kg} \mathrm{~m}^{-3}$ was not strong enough to provoke cascading into the canyon beyond $350 \mathrm{~m}$ depth (Martín et al., 2013). GoL shelf water preferentially flowed toward the Spanish shelf, and only a part was drained by the canyon, following the upper slope before joining the Northern Current and 
hence contributing to the Winter Intermediate Water mass (WIW) that is found around the shelf break depth $(200 \mathrm{~m})$. These characteristics are similar to those of winter 2003-2004, for which Ulses et al. (2008a) noted negligible quantities of exported water denser than $28.82 \mathrm{~kg}$ $\mathrm{m}^{-3}$. These two winters belong to the first regime.

In contrast, during winter 2004-2005, density anomalies higher than $29.2 \mathrm{~kg} \mathrm{~m}^{-3}$ (Canals et al., 2006; Font et al., 2007) were measured in the canyon and allowed the cascading to reach the bottom of the basin (2500 $\mathrm{m}$ deep) (Palanques et al., 2009). This second regime also concerned the winters of 2005-2006 (Palanques et al., 2012) and 2011-2012 (Durrieu de Madron et al., 2013).

For these two regimes, it seems that exports during the studied winters are of the same magnitude: $1500 \mathrm{~km}^{3}$ in winter 2010-2011 (this study) and $1640 \mathrm{~km}^{3}$ for dense water only, in winter 2004-2005 Ulses et al. (2008a). Therefore, the major difference between these two regimes may concern the volume exported less than the preferential export pathways. During the mild winter of 2010-2011, according to our estimates, 30\% of export took place through the CCC and 70\% along the coast. This distribution is inverted with respect to that found by Ulses et al. (2008c) for the cold winter 2004-2005, when $69 \%$ of the export passed through the canyon. The two export pathways are clearly distinguished by the impacts on ecosystems and human activities associated with the pollutants advected by the GoL water masses (contaminants in dissolved or particulate form delivered regularly or under accidental conditions, organic matter, microplastics, etc.). In the first case, these are coastal impacts on anthropized environments (fishing, aquaculture, tourism) and coastal ecosystems. In the second case, impacts inside the canyon at several hundred metres depth may concern specific habitats that are relatively protected from human activities (e.g. cold water corals, which benefit from sporadic coastal exports that provide them with food).

In order to estimate the proportion of GoL shelf waters that flow towards the Spanish shelf or towards the intermediate and deep basin over a decade, criteria influencing the export were computed for winters 2009-2010 to 2016-2017 using ECMWF short-term forecasts (see section 2.1.3.3): the number of days of easterly and northerly wind (with a daily mean velocity greater 
than $8 \mathrm{~m} \mathrm{~s}^{-1}$ ) and winter surface heat fluxes (Table 2).

The winter 2010-2011, studied here, had 10 days of easterly wind (the maximum over the 8 ¡winters is 11) while 2011-2012, known to be a major year of dense water formation (Durrieu de Madron et al., 2013), had only one (the minimum value). Moreover, although the winter heat loss in 2011-2012 was indeed high (ranking second after 2014-2015), which is consistent with the formation of dense water, the year 2010-2011 was rather close to the average (3 years have been significantly warmer). However, considering only February and March, 2011-2012 becomes by far the coldest of the series while 2010-2011 becomes the second warmest. If, on the other hand, heat losses were considered only in December and January, this ranking would be reversed, with 2010-2011 being colder than 2011-2012, which contradicts the observations of water density and temperature (Bourrin et al., 2015; Durrieu de Madron et al., 2013). Dense exception with a first deep cascading event in early January due to a long period of high heat losses from mid-November to late December (Palanques et al., 2012). This seems to support the idea that the heat losses during late winter (February-March) are most often crucial for the formation of very dense water.

775 mild winters that would be, from warmest to coldest, 2016-2017, 2010-2011, 2013-2014, followed by 2015-2016, which was close to the average. The two warmest years had the largest number of easterly wind events, which should produce high export of light water along the Spanish coast. At the other end of the range, going from the coldest to the warmest, the extreme which is close to the average. This ranking is partially corroborated by the fact that cold water was observed along the bottom at $1000 \mathrm{~m}$ depth in 2012-2013 at the long-term mooring of the Lacaze-Duthiers Canyon (Durrieu de Madron pers. comm.) but, unlike for 2011-2012, no signal was detected in the abyssal plain (Estournel et al., 2016, Houpert et al., 2016). In 2009-2010, 785 cold water was also detected at the Lacaze-Duthiers Canyon mooring but only $500 \mathrm{~m}$ above the bottom, while pulses of particle fluxes measured by sediment traps in the CCC suggest that 
the cascading would have reached $1000 \mathrm{~m}$ there (Rumín-Caparrós et al., 2013). An anomaly of our ranking would be 2014-2015, for which no cold water signal was observed at either 500 m or $1000 \mathrm{~m}$ depths in Lacaze-Duthiers Canyon, indicating that the process is more complex than suggested above. An example of other processes could be the river water inputs, which might influence the density of coastal water (Ulses et al. 2008c). Typically, the formation of dense water during the winters of 2004-2005 and 2011-2012, which was clearly predominantly induced by strong heat losses, could have been facilitated by very low discharges of the Rhône and other rivers (Canals et al., 2006).

To conclude, 4 of the 8 winters (2010-2011, 2013-2014, 2015-2016 and 2016-2017) studied here seem to be into the mild regime, while 3 or 4 (2009-2010, 2011-2012 , 2012-2013 and uncertain 2014-2015) are to be included in the cold regime. This suggests, on average, comparable exports through the coastal strip and the canyon. More prolonged, multi-year simulations are needed to obtain a more refined quantification of the interannual variability of water export out of the GoL. Additionally, the maintenance of long-term observations on the shelf (POEM station and repeated glider transects) and in the CCC during the autumn-winter period, would be an effective means of monitoring the key parameters (currents, water temperature and salinity), in this crucial region and thus improve also the validation of export quantifications obtained with numerical models. 
Table 2: Winter average of the heat flux and number of days with wind stronger than $8 \mathrm{~m} \mathrm{~s}^{-1}$ for 8 winters, and the average of these winters (source ECMWF). The blue numbers correspond to values significantly above average. The year highlighted in blue is a year of strong cascading. The year highlighted in pink is the one studied in this paper.

\begin{tabular}{|c|c|c|c|}
\hline Winter & Months & Heat Flux $\left(\mathrm{W} \mathrm{m}^{-2}\right)$ & $\begin{array}{l}\text { Number of days of wind } \\
\text { from easterly / northerly }\end{array}$ \\
\hline \multirow{2}{*}{ 2009-2010 } & Dec-Mar & -163 & \multirow{2}{*}{$6 / 38$} \\
\hline & Dec-Jan / Feb-Mar & $-235 /-88$ & \\
\hline $2010-2011$ & $\begin{array}{c}\text { Dec-Mar } \\
\text { Dec-Jan / Feb-Mar }\end{array}$ & $\begin{array}{c}-138 \\
-234 /-37\end{array}$ & $10 / 34$ \\
\hline 2011-2012 & $\begin{array}{c}\text { Dec-Mar } \\
\text { Dec-Jan / Feb-Mar }\end{array}$ & $\begin{array}{c}-184 \\
-201 /-167\end{array}$ & $1 / 54$ \\
\hline \multirow{2}{*}{$2012-2013$} & Dec-Mar & -164 & \multirow{2}{*}{$7 / 47$} \\
\hline & Dec-Jan / Feb-Mar & $-212 /-115$ & \\
\hline \multirow{2}{*}{$2013-2014$} & Dec-Mar & -95 & \multirow{2}{*}{$4 / 29$} \\
\hline & Dec-Jan / Feb-Mar & $-139 /-49$ & \\
\hline \multirow{2}{*}{$2014-2015$} & Dec-Mar & -205 & \multirow{2}{*}{$1 / 59$} \\
\hline & Dec-Jan / Feb-Mar & $-295 /-111$ & \\
\hline \multirow{2}{*}{$2015-2016$} & Dec-Mar & -87 & \multirow{2}{*}{$4 / 28$} \\
\hline & Dec-Jan / Feb-Mar & $-96 /-79$ & \\
\hline \multirow{2}{*}{$2016-2017$} & Dec-Mar & -125 & \multirow{2}{*}{$11 / 31$} \\
\hline & Dec-Jan / Feb-Mar & $-230 /-16$ & \\
\hline \multirow{2}{*}{ 2009-2017 (average) } & Average & -145 & \multirow{2}{*}{$5.5 / 40$} \\
\hline & Dec-Jan / Feb-Mar & $-205 /-83$ & \\
\hline
\end{tabular}


We have demonstrated the capabilities of a coupled ocean-wave model to reproduce the currents and the hydrology of the Gulf of Lion shelf and of the Cap de Creus Canyon during the autumn and winter 2010-2011. The simulation shows good performance in representing the timing of the various intense current events on the shelf and in the canyon. The year under study had a windy autumn with a long, violent eastern storm in October followed by numerous storms, and a calmer, mild winter with, on average, little heat loss. These characteristics explain the difference in the residence time of the water near the Rhône river mouth: 10-40 days for autumn 2010, and 40-60 days for winter 2010-2011. The contrast between autumn and winter is marked in terms of the quantity of water exported but also, and above all, of the export depth. The total export was $747 \mathrm{~km}^{3}$ in autumn against $1513 \mathrm{~km}^{3}$ in winter. The major source of uncertainty seems to be an overestimation of the cascading, which could result in an excess of $150 \mathrm{~km}^{3}$ for the winter transport through the canyon. In autumn, the volume of water exported in the Cap de Creus canyon below $200 \mathrm{~m}$ represents $4 \%$ of total export while, in winter, this value rises to nearly $25 \%$, representing $385 \mathrm{~km}^{3}$ of coastal waters However, their density did not allow them to cascade below 500-600 m.

Our study shows that the succession and duration of strong wind episodes have a major effect on the residence times of freshened waters influenced by the Rhône River, notably by increasing the cross-slope exchanges of coastal waters in the eastern part of the Gulf of Lion. Northerly winds, which are by far the most frequent, advect the light coastal waters offshore where they could be entrained by the Northern Current and then transported over long distances along the slope. At the south-western exit of the Gulf of Lion, rare sustained easterly winds systematically produce significant export (the two major periods of storms of October and March, that are periods 1 and 4, would account for $44 \%$ of total export). Outside these periods, the situation is contrasted, with a quasi systematic net export mainly during the winter period, due to the increased density of the shelf waters, while, in autumn, export and import periods alternate. It can be noted that, during winter, short events of moderate easterly winds are sufficient to reactivate or strengthen cascading by advecting dense water from the shelf to the southwestern 
Gulf of Lion export area. This process is likely to be more important during mild winters when the density of shelf water is moderate and induced gravity currents are weak. The major export pathways are therefore located to the south-west through the narrow coastal strip bordering the Cap de Creus promontory and through the Cap de Creus Canyon. The distinction between these two pathways is important because the associated impacts in terms of food or contaminant inputs are different. The results obtained in this paper and previous results in the literature indicate that the percentage of exports via the coastal strip and the canyon could vary from $30 \%$ to $70 \%$ on average over the year, with the coastal strip or the canyon being favoured during mild winters and cold winters respectively. Specifically within the canyon, the areas affected by shelf water export in the autumn would be limited to less than $200 \mathrm{~m}$ deep In winter, they would systematically concern the first few hundred meters (exceeding 500 meters very sporadically) while, in the coldest years, they would reach 1000 to $1500 \mathrm{~m}$ and could even affect the whole canyon in the extreme cases. The statistical study conducted over 8 winters (2010-2017) and focusing on the surface heat fluxes that are the first-order drivers of the densification of the coastal water suggests that the late winter heat fluxes (February-March) would be a factor determining whether deep cascading $(\sim 1000 \mathrm{~m})$ is triggered or not. During the period under consideration, deep cascading would represent 3 or 4 years out of 8 , with the export pathway dominated, in one case, by the coastal strip and, in the other case, by the Cap de Creus Canyon. 


\section{Acknowledgments}

This work was supported by ANR AMORAD grant ANR-11-RSNR-0002 of the French Agence Nationale de la Recherche and the MISTRALS-MERMEX Programme. The PhD fellowship of G.M. was also funded by AMORAD. The simulations were performed using HPC resources from CALMIP (Grants P09115, P1325 and P1331) and CINES OCCIGEN (Grant A0040110088). The MesuRho data were processed in the framework of the MATUGLI ANR grant and the OSR5 programme. 


\section{References}

Ardhuin, F., Rascle, N., Belibassakis, K., 2008. Explicit wave-averaged primitive equations

using a generalized Lagrangian mean. Ocean Modelling 20, 35-60. doi:10.1016/j.ocemod. 2007.07 .001

Barrier, N., Petrenko, A.A., Ourmières, Y., 2016. Strong intrusions of the Northern Mediterranean Current on the eastern Gulf of Lion: insights from in-situ observations and high resolution numerical modelling. Ocean Dynamics 66, 313-327. doi 10.1007/s10236-016-0921-7.

Bentsen, M., Evensen, G., Drange, H., Jenkins, A.D., 1999. Coordinate Transformation on a Sphere Using Conformal Mapping. Monthly Weather Review 127, 2733-2740. doi:10.1175/ 1520-0493(1999) 127<2733: CTOASU>2.0.C0;2.

Bourrin, F., Many, G., Durrieu de Madron, X., Martín, J., Puig, P., Houpert, L., Testor, P., Kunesch, S., Mahiouz, K., Béguery, L., 2015. Glider monitoring of shelf suspended particle dynamics and transport during storm and flooding conditions. Continental Shelf Research 109, 135-149. doi:10.1016/j.csr.2015.08.031.

Braunschweig, F., Martins, F., Chambel, P., Neves, R., 2003. A methodology to estimate renewal time scales in estuaries: the Tagus Estuary case. Ocean Dynamics 53, 137-145. doi: $10.1007 / \mathrm{s} 10236-003-0040-0$.

Canals, M., Puig, P., de Madron, X.D., Heussner, S., Palanques, A., Fabres, J., 2006. Flushing submarine canyons. Nature 444, 354-357. doi:10.1038/nature05271.

Carrere, L., Lyard, F., Cancet, M., Guillot, A., Roblou, L., 2013. FES 2012: a new global tidal model taking advantage of nearly 20 years of altimetry, in: 20 Years of Progress in Radar Altimetry.

Dabrowski, T., Hartnett, M., Olbert, A., 2010. Influence of seasonal circulation on flushing of the Irish Sea. Marine Pollution Bulletin 60, 748-758. doi:10.1016/j.marpolbul.2009.11. 018 
Davis, R., Eriksen, C., Jones, C., 2003. Autonomous buoyancy-driven underwater vehicle gliders. Technology and applications of autonomous underwater vehicles Griffiths G, Ed., $37-62$.

Dufau-Julliand, C., 2004. Three-dimensional modeling of the Gulf of Lion's hydrodynamics (northwest Mediterranean) during January 1999 (MOOGLI3 Experiment) and late winter 1999: Western Mediterranean Intermediate Water's (WIW's) formation and its cascading over the shelf break. Journal of Geophysical Research 109. doi:10.1029/2003JC002019.

Estournel, C., Auclair, F., Lux, M., Nguyen, C., Marsaleix, P., 2009. "Scale oriented" embedded modeling of the North-Western Mediterranean in the frame of MFSTEP. Ocean Science 5, 73-90. doi:10.5194/os-5-73-2009.

Estournel, C., Kondrachoff, V., Marsaleix, P., Vehil, R., 1997. The plume of the Rhone: 口 numerical simulation and remote sensing. Continental Shelf Research 17, 899-924. doi:10. 1016/S0278-4343(96)00064-7.

Estournel, C., Durrieu de Madron, X., Marsaleix, P., Auclair, F., Julliand, C., Vehil, R., 2003. Observation and modeling of the winter coastal oceanic circulation in the gulf of lion under wind conditions influenced by the continental orography (fetch experiment). Journal of Geophysical Research: Oceans 108. doi:10.1029/2001JC000825, arXiv:https://agupubs.onlinelibrary.wiley.com/doi/pdf/10.1029/2001JC000825.

Estournel, C., Testor, P., Damien, P., D’Ortenzio, F., Marsaleix, P., Conan, P., Kessouri, F., Durrieu de Madron, X., Coppola, L., Lellouche, J.M., Belamari, S., Mortier, L., Ulses, C., Bouin, M.N., Prieur, L., 2016. High resolution modeling of dense water formation in the north-western Mediterranean during winter 2012-2013: Processes and budget. Journal of Geophysical Research: Oceans 121, 5367-5392. doi:10.1002/2016JC011935.

Font, J., Puig, P., Salat, J., Palanques, A., Emelianov, M., 2007. Sequence of hydrographic changes in NW Mediterranean deep water due to the exceptional winter of 2005. Scientia Marina 71, 339-346. doi:10.3989/scimar.2007.71n2339. 
Gangloff, A., Verney, R., Doxaran, D., Ody, A., Estournel, C., 2017. Investigating Rhône River 2017.06 .024 .

Gatti, J., Petrenko, A., Devenon, J.L., Leredde, Y., Ulses, C., 2006. The Rhone river dilution zone present in the northeastern shelf of the Gulf of Lion in December 2003. Continental

Oceans 121, 8139-8171. doi:10.1002/2016JC011857.

Kjerfve, B., Magill, K., 1989. Geographic and hydrodynamic characteristics of shallow coastal lagoons. Marine Geology 88, 187-199. doi:10.1016/0025-3227(89)90097-2.

Large, W., Yeager, S., 2004. Diurnal to decadal global forcing for ocean and sea-ice models: The 925 data sets and flux climatologies. Technical Report. UCAR/NCAR. doi:10.5065/D6KK98Q6.

Lee, T.N., Rooth, C., Williams, E., McGowan, M., Szmant, A.F., Clarke, M., 1992. Influence of Florida Current, gyres and wind-driven circulation on transport of larvae and recruitment q in the Florida Keys coral reefs. Continental Shelf Research 12, 971-1002. doi:10.1016/ 0278-4343(92) 90055-0.

Lellouche, J.M., Le Galloudec, O., Drévillon, M., Régnier, C., Greiner, E., Garric, G., Ferry, N., Desportes, C., Testut, C.E., Bricaud, C., Bourdallé-Badie, R., Tranchant, B., Benkiran, M., Drillet, Y., Daudin, A., De Nicola, C., 2013. Evaluation of global monitoring and forecasting systems at Mercator Océan. Ocean Science 9, 57-81. doi:10.5194/os-9-57-2013. 
Leredde, Y., Denamiel, C., Brambilla, E., Lauer-Leredde, C., Bouchette, F., Marsaleix, P., 2007. Hydrodynamics in the Gulf of Aigues-Mortes, NW Mediterranean Sea: In situ and modelling data. Continental Shelf Research 27, 2389-2406. doi:10.1016/j.csr.2007.06.006.

Liu, Z., Wei, H., Liu, G., Zhang, J., 2004. Simulation of water exchange in Jiaozhou Bay by $\square$ average residence time approach. Estuarine, Coastal and Shelf Science 61, 25-35. doi:10. $1016 /$ j.ecss. 2004.04.009.

Durrieu de Madron, X., Houpert, L., Puig, P., Sanchez-Vidal, A., Testor, P., Bosse, A., Estournel, C., Somot, S., Bourrin, F., Bouin, M.N., Beauverger, M., Beguery, L., Calafat, A., Canals, M., Cassou, C., Coppola, L., Dausse, D., D’Ortenzio, F., Font, J., Heussner, S., Kunesch, S., Lefevre, D., Le Goff, H., Martín, J., Mortier, L., Palanques, A., Raimbault, P., 2013. Interaction of dense shelf water cascading and open-sea convection in the northwestern Mediterranean during winter 2012. Geophysical Research Letters 40, 1379-1385. doi:10.1002/grl.50331.

Many, G., Bourrin, F., de Madron, X.D., Pairaud, I., Gangloff, A., Doxaran, D., Ody, A., Verney, R., Menniti, C., Le Berre, D., others, 2016. Particle assemblage characterization in the Rhone River ROFI. Journal of Marine Systems 157, 39-51.

Marsaleix, P., Auclair, F., Duhaut, T., Estournel, C., Nguyen, C., Ulses, C., 2012. Alternatives (1) to the Robert-Asselin filter. Ocean Modelling 41, 53-66. doi:10.1016/j.ocemod.2011.11. 002.

Marsaleix, P., Auclair, F., Estournel, C., 2009. Low-order pressure gradient schemes in sigma q coordinate models: The seamount test revisited. Ocean Modelling 30, 169-177. doi:10.1016/ j.ocemod.2009.06.011.

Marsaleix, P., Auclair, F., Floor, J.W., Herrmann, M.J., Estournel, C., Pairaud, I., Ulses, C., 2008. Energy conservation issues in sigma-coordinate free-surface ocean models. Ocean Modelling 20, 61-89. doi:10.1016/j.ocemod.2007.07.005. 
Martín, J., Durrieu de Madron, X., Puig, P., Bourrin, F., Palanques, A., Houpert, L., Higueras, M., Sanchez-Vidal, A., Calafat, A.M., Canals, M., Heussner, S., Delsaut, N., Sotin, C., 2013. Sediment transport along the Cap de Creus Canyon flank during a mild, wet winter. Biogeosciences 10, 3221-3239. doi:10.5194/bg-10-3221-2013.

Michaud, H., Marsaleix, P., Leredde, Y., Estournel, C., Bourrin, F., Lyard, F., Mayet, C., Ardhuin, F., 2012. Three-dimensional modelling of wave-induced current from the surf zone to the inner shelf. Ocean Science 8, 657-681. doi:10.5194/os-8-657-2012.

Millot, C., 1990. The Gulf of Lions' hydrodynamics. Continental Shelf Research 10, 885-894. doi: $10.1016 / 0278-4343(90) 90065-\mathrm{T}$.

Millot, C., 1999. Circulation in the western Mediterranean Sea. Journal of Marine Systems 20, $423-442$.

Monsen, N.E., Cloern, J.E., Lucas, L.V., Monismith, S.G., 2002. A comment on the use of flushing time, residence time, and age as transport time scales. Limnology and Oceanography 47, 1545-1553. doi:10.4319/10.2002.47.5.1545.

Nikiema, O., Devenon, J.L., Baklouti, M., 2007. Numerical modeling of the Amazon River plume. Continental Shelf Research 27, 873-899. doi:10.1016/j.csr.2006.12.004.

Pairaud, I., Lyard, F., Auclair, F., Letellier, T., Marsaleix, P., 2008. Dynamics of the semidiurnal and quarter-diurnal internal tides in the Bay of Biscay. Part 1: Barotropic tides. Continental Shelf Research 28, 1294-1315. doi:10.1016/j.csr.2008.03.004.

Pairaud, I., Repecaud, M., Ravel, C., Fuchs, R., Arnaud, M., Champelovier, A., Rabouille, C., Bombled, B., Toussaint, F., Garcia, F., Raimbault, P., Verney, R., Meule, S., Gaufres, P., Bonat, A., Cadiou, J.F., 2016. MesuRho. Plateforme instrumentée de suivi des paramètres environnementaux à l'embouchure du Rhône., in: Mesures à haute résolution dans l'environnement marin côtier. 2016. Schmitt, F.G. et Lefebvre A. (Eds.). CNRS Alpha, pp. $73-87$. 
Palanques, A., Guillén, J., Puig, P., Durrieu de Madron, X., 2008. Storm-driven shelf-to-canyon suspended sediment transport at the southwestern Gulf of Lions. Continental Shelf Research 28, 1947-1956. doi $10.1016 /$ j.csr.2008.03.020.

Palanques, A., Durrieu de Madron, X., Puig, P., Fabres, J., Guillén, J., Calafat, A., Canals, M., Heussner, S., Bonnin, J., 2006. Suspended sediment fluxes and transport processes in the Gulf of Lions submarine canyons. The role of storms and dense water cascading. Marine Geology 234, 43-61. doi:10.1016/j.margeo.2006.09.002.

Palanques, A., Puig, P., Latasa, M., Scharek, R., 2009. Deep sediment transport induced by storms and dense shelf-water cascading in the northwestern Mediterranean basin. Deep Sea (1) Research Part I: Oceanographic Research Papers 56, 425-434. doi:10.1016/j.dsr.2008. 11.002

Palanques, A., Puig, P., Durrieu de Madron, X., Sanchez-Vidal, A., Pasqual, C., Martín, J., Calafat, A., Heussner, S., Canals, M., 2012. Sediment transport to the deep canyons and open-slope of the western Gulf of Lions during the 2006 intense cascading and open-sea convection period. Progress in Oceanography 106, 1-15. doi $10.1016 / \mathrm{j}$.pocean.2012.05. 002 .

Petrenko, A., Dufau, C., Estournel, C., 2008. Barotropic eastward currents in the western Gulf of Lion, north-western Mediterranean Sea, during stratified conditions. Journal of Marine Systems 74, 406-428. doi $10.1016 / \mathrm{j} \cdot \mathrm{jmarsys.2008.03.004.}$

Puig, P., Palanques, A., Orange, D., Lastras, G., Canals, M., 2008. Dense shelf water cascades and sedimentary furrow formation in the Cap de Creus Canyon, northwestern Mediterranean Sea. Continental Shelf Research 28, 2017-2030. doi:10.1016/j.csr.2008.05.002.

Rasmussen, B., Josefson, A., 2002. Consistent Estimates for the Residence Time of Micro-tidal Estuaries. Estuarine, Coastal and Shelf Science 54, 65-73. doi:10.1006/ecss.2001.0836.

Rumín-Caparrós, A., Sanchez-Vidal, A., Calafat, A., Canals, M., Martín, J., Puig, P., PedrosaPàmies, R., 2013. External forcings, oceanographic processes and particle flux dynamics in 
Cap de Creus submarine canyon, NW Mediterranean Sea. Biogeosciences 10, 3493-3505. doi:10.5194/bg-10-3493-2013.

Sadaoui, M., Ludwig, W., Bourrin, F., Raimbault, P., 2016. Controls, budgets and variability of riverine sediment fluxes to the Gulf of Lions (NW Mediterranean Sea). Journal of Hydrology 540, 1002-1015. doi:10.1016/j.jhydrol.2016.07.012.

Safak, I., Wiberg, P., Richardson, D., Kurum, M., 2015. Controls on residence time and exchange in a system of shallow coastal bays. Continental Shelf Research 97, 7-20. doi:10. $1016 / j . c s r .2015 .01 .009$.

Schroeder, K., Millot, C., Bengara, L., Ben Ismail, S., Bensi, M., Borghini, M., Budillon, G., Cardin, V., Coppola, L., Curtil, C., Drago, A., El Moumni, B., Font, J., Fuda, J.L., García-Lafuente, J., Gasparini, G.P., Kontoyiannis, H., Lefevre, D., Puig, P., Raimbault, P., Rougier, G., Salat, J., Sammari, C., Sánchez Garrido, J.C., Sanchez-Roman, A., Sparnocchia, S., Tamburini, C., Taupier-Letage, I., Theocharis, A., Vargas-Yáñez, M., Vetrano, A., 2013. Long-term monitoring programme of the hydrological variability in the Mediterranean Sea: a first overview of the HYDROCHANGES network. Ocean Science 9, 301-324. doi:10.5194/ os-9-301-2013.

Seyfried, L., Marsaleix, P., Richard, E., Estournel, C., 2017. Modelling deep-water formation in the North-West Mediterranean Sea with a new air-sea coupled model: sensitivity to turbulent flux parameterizations. Ocean Science , 1093-1112doi:10.5194/os-13-1093-2017.

Tolman, H.L., others, 2009. User manual and system documentation of WAVEWATCH III TM version 3.14. Technical note, MMAB Contribution 276.

Uchiyama, Y., McWilliams, J.C., Shchepetkin, A.F., 2010. Wave-current interaction in an oceanic circulation model with a vortex-force formalism: Application to the surf zone. Ocean Modelling 34, 16-35. doi:10.1016/j.ocemod.2010.04.002.

Ulses, C., Estournel, C., Bonnin, J., Durrieu de Madron, X., Marsaleix, P., 2008a. Impact 
of storms and dense water cascading on shelf-slope exchanges in the Gulf of Lion (NW Mediterranean). Journal of Geophysical Research 113. doi:10.1029/2006 JC003795.

Ulses, C., Estournel, C., Durrieu de Madron, X., Palanques, A., 2008b. Suspended sediment transport in the Gulf of Lions (NW Mediterranean): Impact of extreme storms and floods. Continental Shelf Research 28, 2048-2070. doi:10.1016/j.csr.2008.01.015.

Ulses, C., Estournel, C., Puig, P., Durrieu de Madron, X., Marsaleix, P., 2008c. Dense shelf water cascading in the northwestern Mediterranean during the cold winter 2005: Quantification of the export through the Gulf of Lion and the Catalan margin. Geophysical Research Letters 35, L07610. doi:10.1029/2008GL033257.

Voldoire, A., Decharme, B., Pianezze, J., Lebeaupin Brossier, C., Sevault, F., Seyfried, L., Gar1045 nier, V., Bielli, S., Valcke, S., Alias, A., Accensi, M., Ardhuin, F., Bouin, M.N., Ducrocq, V., Faroux, S., Giordani, H., Léger, F., Marsaleix, P., Rainaud, R., Redelsperger, J.L., Richard, E., Riette, S., 2017. SURFEX v8.0 interface with OASIS3-MCT to couple atmosphere with hydrology, ocean, waves and sea-ice models, from coastal to global scales. Geosci. Model Dev. 10, 4207-4227. doi:10.5194/gmd-10-4207-2017. 